NBER WORKING PAPER SERIES

\title{
CHANNELING REMITTANCES TO EDUCATION: A FIELD EXPERIMENT AMONG MIGRANTS FROM EL SALVADOR
}

\author{
Kate Ambler \\ Diego Aycinena \\ Dean Yang \\ Working Paper 20262 \\ http://www.nber.org/papers/w20262
NATIONAL BUREAU OF ECONOMIC RESEARCH
1050 Massachusetts Avenue
Cambridge, MA 02138
June 2014

This paper was previously circulated under the title "Subsidizing Remittances for Education." Ambler: Markets, Trade, and Institutions Division, International Food Policy Research Institute (k.ambler@cgiar.org). Aycinena: Facultad de Ciencias Económicas, Universidad Francisco Marroquin (diegoaa@ufm.edu). Yang (corresponding author): Department of Economics and Gerald R. Ford School of Public Policy, University of Michigan, NBER, and BREAD (deanyang@umich.edu). Jessica Snyder and Kevin Carney, our Innovations for Poverty Action project associates, deserve special thanks for superb work on all aspects of project implementation and data management. We greatly appreciate the support and feedback of Luis Alejos Marroquín, Oriana Bandiera, Ana de Bardi, Paul Dwyer, Daniel Gottschalk, Patricia Guinea de Solorzano, Gabriela Inchauste, Celia Medrano, Moy Pascual de Velasco, Enilson Solano, Eugenia Suay de Castrillo, and seminar participants at Columbia University, the Inter-American Development Bank, Queens College, Central Michigan University, NEUDC 2013, and the NBER Education Program meeting at the Chicago Fed (November 2013). This project would not have been possible without the collaboration of Fundación Empresarial para el Desarrollo Educativo (FEPADE), Viamericas Corporation, and the Salvadoran consulates in Woodbridge, VA and Washington, DC. This study was funded by the Inter-American Development Bank (contract C0016-11) and by the University of Michigan's Population Studies Center. Ambler acknowledges support from an NICHD training grant to the Population Studies Center at the University of Michigan (T32 HD007339). The views expressed herein are those of the authors and do not necessarily reflect the views of the National Bureau of Economic Research.

NBER working papers are circulated for discussion and comment purposes. They have not been peerreviewed or been subject to the review by the NBER Board of Directors that accompanies official NBER publications.

(C) 2014 by Kate Ambler, Diego Aycinena, and Dean Yang. All rights reserved. Short sections of text, not to exceed two paragraphs, may be quoted without explicit permission provided that full credit, including (C) notice, is given to the source. 
Channeling Remittances to Education: A Field Experiment Among Migrants from El Salvador Kate Ambler, Diego Aycinena, and Dean Yang

NBER Working Paper No. 20262

June 2014

JEL No. C93,F22,F24,H24,I22,J15,O15

\section{ABSTRACT}

We implement a randomized experiment offering Salvadoran migrants matching funds for educational remittances, which are channeled directly to a beneficiary student in El Salvador chosen by the migrant. The matches lead to increased educational expenditures, higher private school attendance, and lower labor supply of youths in El Salvador households connected to migrant study participants. We find substantial "crowd-in" of educational investments: for each $\$ 1$ received by beneficiaries, educational expenditures increase by $\$ 3.72$. We find no shifting of expenditures away from other students, and no effect on remittances.

Kate Ambler International Food Policy Research Institute 2033 K St, NW

Washington, DC 20006

k.ambler@cgiar.org

Diego Aycinena

Universidad Francisco Marroquín

6a calle final zona 10

Edificio Académico, Oficina E-503

Ciudad de Guatemala

Guatemala

diegoaa@ufm.edu
Dean Yang

University of Michigan

Department of Economics and

Gerald R. Ford School of Public Policy

735 S. State Street, Room 3316

Ann Arbor, MI 48109

and NBER

deanyang@umich.edu 


\section{Introduction}

On a global scale, migrant remittances are one of the largest types of international financial flows to developing countries, amounting in 2012 to over US\$400 billion (World Bank 2012). By contrast, developing country receipts of official foreign development assistance in 2012 amounted to just US\$126 billion (OECD 2013). While migrant remittance flows are large in magnitude, they amount to only a minority of the total developed-country earnings of migrant workers from developing countries (Clemens et al. 2009, Clemens 2011, Yang 2011). The prospect that migrants might be encouraged to send even more remittances, and that these remittances might be better leveraged for the economic development of migrant-origin countries, has led to substantial interest in academic and policy circles in development policies related to migrant remittances. ${ }^{1}$

A type of remittance-related program that has generated particular interest is a matching program to stimulate the use of remittances for investment in migrantorigin countries. Such programs have been implemented by home country governments, but to date have not been rigorously evaluated. For example, the Mexican “Tres por Uno” (“Three for One”) program encourages Mexican migrants abroad to invest in their communities of origin. Each dollar invested by migrants is matched by $\$ 3$ from the Mexican government. Migrants have contributed an average of \$15 million annually since the program began (Hazán 2012). Additionally, there has been particular interest in enhancing the positive impacts of remittances on education. Existing research provides evidence of positive impacts of migration and remittances on educational outcomes in migrant-origin countries (Cox-Edwards and Ureta 2003; Yang 2008; Theoharides 2014).

In this paper, we study a novel program that seeks to stimulate migrant

\footnotetext{
${ }^{1}$ Policy-oriented publications include Pew Hispanic Center (2002), Terry and Wilson (2005), and World Bank (2006, 2007). Yang (2011) reviews recent research on the economics of migrant remittances.
} 
remittances for educational purposes by providing subsidies in the form of matching funds. The program's target population is migrants from El Salvador and households in the home country that are connected to these migrants. We designed and offered migrants a new product, named "EduRemesa," which allowed migrants to channel funds towards the education of a student of their choice in El Salvador for the 2012 school year. ${ }^{2}$ EduRemesa beneficiary students in El Salvador received an ATM card in their name, providing access to the funds, and were told that the funds were for expenditures related to their own education.

We conducted a randomized controlled trial to measure take-up and impacts of the EduRemesa at various levels of matching funds. We randomly assigned migrants (recruited in metro Washington, DC) to a control group or one of a number of treatment conditions which varied in the degree to which our research project matched EduRemesa funds for the beneficiary student. In the "3:1 match" treatment, each dollar contributed by the migrant was matched with $\$ 3$ in project funds. In the "1:1 match" treatment, each dollar contributed by the migrant was matched with $\$ 1$ in project funds. In a third treatment group ("no match”), migrants were simply offered the EduRemesa product without matching funds.

Several months after the EduRemesa offers to migrants, we conducted follow-up surveys to establish impacts of our treatments. Migrants could have sent EduRemesas to many possible students in El Salvador, so it was important that at baseline we elicited from migrants, in both the control and treatment groups, a "target" student whom they would be likely to fund if offered the EduRemesa product. Our measurement of impacts in El Salvador relies on surveys of these target students, and of a knowledgeable adult in the student's household.

Our first key finding is that take-up of the EduRemesa was monotonically related to the match level. $18.5 \%$ of migrants in the 3:1 match treatment executed

\footnotetext{
2 "Remesa" is the Spanish word for "remittance." The US dollar is the national currency of El
} Salvador. 
at least one EduRemesa transaction, compared to $6.9 \%$ in the 1:1 match group and exactly zero in the no-match group. $15.1 \%$ and $6.0 \%$ of migrants with the $3: 1$ and 1:1 matches, respectively, sent an EduRemesa to their target student.

These results indicate a high elasticity of demand for channeling remittances towards education with respect to the match rate. The finding of zero demand for the unsubsidized ("no match”) EduRemesa contrasts with other studies that have found that migrants seek greater control over how their remittances are used. Our results may reveal that there is no "pure" or unsubsidized demand for control over the use of remittances for education in this context. However, it is also possible that take-up without the matching funds was dampened by non-trivial transaction costs of using the EduRemesa, as well as liquidity constraints on the part of migrants who had to pay the entire EduRemesa amount up front.

In addition, we find that the 3:1 match treatment leads to large increases in educational expenditures on the target student. We find substantial "crowd-in" of household educational investments in response to the matching funds. Not only are the EduRemesa funds supplementing (rather than substituting for) existing expenditures on education, the funds stimulate additional educational investments on the target student. We find a "crowd-in ratio" (ratio of increased target student educational expenditure to EduRemesa funds received) of 3.72 (each dollar of EduRemesa funds leads to $\$ 3.72$ in additional spending). In addition, the 3:1 match leads to a higher likelihood of attending private school and to lower labor supply on the part of target students. To our knowledge, this is the first research to provide evidence of crowd-in of education expenditures (or any household investment) in response to a subsidy. Crowd-in is clearly a theoretical possibility, simply representing the case where education is a normal good while "all other goods" are collectively inferior goods. ${ }^{3}$

\footnotetext{
${ }^{3}$ Crowd-in becomes more likely (and can be large in magnitude) if increasing consumption of education requires a discrete increase in expenditure. In practice, this could be the case when a
} 
Budget constraints prevented us from fielding full income, consumption and expenditure modules in the follow-up survey, so we are unable to say definitively where the funds for additional crowded-in educational expenditures came from. That said, we can say that these crowded-in funds did not come from additional remittances sent by the migrant, since we find no change in target student household remittance receipts. We also find that increased expenditures on target students are not funded via reductions in expenditures on other students in the household.

This paper is related to research on crowd-out of public transfers, in which findings of incomplete crowd-out are referred to as "flypaper effects” (see Payne's 2009 review). Several papers find no crowd-out of resources within households in response to transfers provided to households for particular purposes, such as Jacoby (2002), Islam and Hoddinott (2009) and Afridi (2010) in the context of child nutrition programs. Shi (2012) documents a flypaper effect in the context of a change in school fees in rural China. Conversely, Das et al. (2013) find crowd-out of household educational expenditures in response to anticipated public grants to schools. The Angrist et al. (2002) study of Colombian private school vouchers comes closest to finding crowd-in in response to a subsidy, but that paper does not provide a formal statistical test of the hypothesis that household educational expenditures rose by more than the value of the subsidy. ${ }^{4}$ In contrast to these studies, we find evidence of crowd-in of household resources in response to a

subsidy induces a shift from public to private school, and where private schools require discretely higher expenditures. Peltzman (1973) makes a version of the same point, showing theoretically and empirically how subsidies for higher education in the form of state universities can lead to overall reductions in expenditures on higher education because the subsidy is in-kind and not valid at private institutions. Our results are consistent with this possibility, in that the match leads to large increases in private school attendance, and that typical expenditures on private schools in El Salvador are substantially higher than on public schooling.

${ }^{4}$ The Angrist et al (2002) crowd-in ratio of 1.26 incorporates the opportunity cost of student labor hours (which fell in response to the voucher). The corresponding figure in our study is therefore 5.38 (column 3, Table 6), which similarly takes into account the opportunity cost of student time. Exclusive of the opportunity cost of student time, Angrist et al. (2002) estimate a crowd-in ratio of 0.70 ; in our study the corresponding figure is 3.72 (column 1, Table 6). 
transfer that is large in magnitude and statistically significant. ${ }^{5}$

Our work is also related to the literature on cash transfers and education. ${ }^{6}$ While existing studies have not examined impacts on education expenditures, ${ }^{7}$ our results are reminiscent of certain findings in that literature. Baird et al. (2011) and Edmonds and Schady (2012) find large effects of unconditional cash transfers on school attendance, implying substantial elasticities of attendance with respect to income. Angelucci et al. (2009) find that the Mexican conditional cash transfer program increased secondary school enrollment only when eligible secondary school students had eligible primary school students in their family network. Transfers to households with a secondary school student appear to have crowded in transfers from other eligible households for secondary students' expenditures.

This paper is organized as follows. Section 2 describes the context and field experimental design. Section 3 provides an overview of the data and sample summary statistics. Section 4 presents the empirical results, and Section 5 concludes and discusses policy implications.

\section{Project Description}

\section{A. Overview of education in El Salvador}

The education system in El Salvador is divided into four levels: primary (grades 1-6), lower secondary or middle school (grades 7-9), secondary (grades 1012), and tertiary. Primary school enrollment rates are high in El Salvador, at 95\% in 2009. However, enrollment quickly falls off at the middle and secondary levels.

\footnotetext{
${ }^{5}$ Carneiro et al. (2012) find that a public health intervention (anti-malarial spraying) crowds in household purchases of another health good (insecticide-treated bednets) in Eritrea, but do not estimate the change in total household health expenditures.

${ }^{6}$ Conditional cash transfer programs now exist in a many countries, and have been shown to lead to increased school enrollment and reduced dropout. Studies include Schultz (2004), Behrman et al (2005), Barrera et al (2011), Baird et al (2011), and Glewwe and Kassouf (2012). Benhassine et al. (2013) show that labeling a cash transfer as intended for education can have similar positive effects on school participation as imposing conditionality. See Fiszbein and Schady (2009) for a review.

${ }^{7}$ Some studies of the impacts of CCTs have gone beyond schooling measures to examine impacts on household consumption (Hoddinott and Skoufias 2004; Angelucci and Attanasio 2009; Angelucci and de Giorgi 2009).
} 
In 2009, enrollment rates in middle and secondary school were only 56\% and 32\% respectively (FUSADES 2011). Although public schools below the tertiary level do not charge tuition or fees in El Salvador, the costs of attending secondary school are nonetheless higher than for primary school. Older students have higher opportunity costs, and secondary schools are often further away and require expenditures on uniforms and school supplies. These characteristics of the El Salvador educational system make it an appropriate setting within which to study a project that is targeted towards secondary and tertiary students.

Most students at the primary and secondary school level in El Salvador study in public schools. Online Appendix Table 1 shows figures from the 2010 Encuesta de Hogares de Propositos Multiples (EHPM), an annual, nationally representative, household survey in El Salvador. 89\% of primary students and 79\% of secondary students attend public schools. At the tertiary level, private institutions are much more important, with $60 \%$ of enrolled students attending a private institution. There are significant cost differences between attending public and private institutions. At both the secondary and tertiary level, average annual expenditures are roughly two-thirds higher in private than in public schools (\$2214 compared to \$1442 for secondary schools and \$2834 compared to \$1868 for tertiary schools). ${ }^{8}$

\section{B. Project overview}

Migrants from El Salvador were recruited to participate in this project at the two locations of the Salvadoran consulate in the Washington, DC area. Baseline field work ran from November 2011 to early February 2012, overlapping with the period between the end of the 2011 school year and the start of the 2012 school year. ${ }^{9}$ While waiting for consular services, migrants were approached by project

\footnotetext{
8 These figures are calculated using the education expenditure data for the control group only, collected during the follow-up survey for this project (to be described below).

${ }^{9}$ Public schools in El Salvador began the school year on January 23, 2012.
} 
staff and asked if they wished to participate in the study. Because the product being evaluated was targeted towards students at the secondary or tertiary level, migrants were required to have a relative in El Salvador who would be eligible for secondary or tertiary studies in the 2012 school year. ${ }^{10}$ Migrants who agreed to participate in the study were administered a baseline survey.

A key objective of this research is to measure impacts on students and households in El Salvador. Thus, a challenge that arises is determining which students and households in El Salvador to survey, since migrants who are offered EduRemesas could use them for students in multiple potential households. In addition, it is important to determine the identity of surveyed students and households in El Salvador in a consistent manner across treatment conditions, so as to avoid the possibility that treatment status would affect which El Salvador student and household the migrant study respondent chose to identify.

Our approach was to identify, for all migrants, the student in El Salvador whom they would prioritize to receive additional educational financing. Our presumption was that this student would be the one they would finance with an EduRemesa (if offered the EduRemesa, and choosing to take up). Specifically, we asked migrants to enter a student of their choosing in El Salvador (who would be eligible for secondary or tertiary schooling in the coming year) into a lottery to receive a \$500 scholarship for the 2012 school year. ${ }^{11}$ This was done at the beginning of the baseline survey, before treatment status was revealed, and so rules out differential selection of target students on the basis of treatment status. We refer to this student as the "target student" and to the student's household as the "target household.” The rest of the baseline survey included questions about demographics,

\footnotetext{
${ }^{10}$ Of those migrants approached, 24\% participated. Of those who did not participate, $77 \%$ did not know an eligible student, $14 \%$ refused, $7 \%$ were not from El Salvador, and 2\% did not participate for other reasons.

${ }^{11}$ Target students were not required to be currently enrolled in school.
} 
remittances, and the target student and household. Immediately following the baseline survey, project staff implemented the randomized treatments. ${ }^{12}$

Follow-up surveys were then conducted from July to October 2012 (the last third of the 2012 school year), in random order. A phone survey of migrant respondents collected information about remittances sent to the target household. We also collected information about the target household via phone surveys, separately interviewing the target student and a knowledgeable adult in the household. Students provided information about their education and labor supply, while the adults provided information related to the education of other students in the household. We use these follow-up surveys, combined with administrative information about the take up of the EduRemesas, to analyze treatment impacts.

\section{Details of EduRemesa treatments}

We partnered with the Fundación Empresarial para el Desarrollo Educativo (FEPADE), ${ }^{13}$ an educational NGO in El Salvador, to develop the EduRemesa. Migrant participants were randomly assigned to be either part of a control group or one of three treatment groups that received offers for the EduRemesa at varying matching levels. In order to avoid spillovers between participants, a first-stage randomization was conducted at the day-by-location level that assigned migrants to either the control group or to a group that would receive an offer of the EduRemesa. On each day and at each location all migrants were either in the control group or not. One third of days were allocated to the control group and two thirds to the EduRemesa group. This randomization was stratified by week and location.

\footnotetext{
${ }^{12}$ Following the conclusion of the baseline interaction with the migrant, the target household in El Salvador was administered a phone survey. These mainly serve to establish a first contact with the El Salvador household, with the intention of reducing attrition in the later follow-up survey. Because some time had passed between the migrant treatment in the United States and the survey in El Salvador (the mean time between surveys was fifteen days), responses and behaviors by El Salvador respondents could have already been influenced by the treatments, so these phone El Salvador surveys cannot be considered baseline data.

${ }^{13}$ In English, "Business Foundation for Educational Development.”
} 
In a second randomization, all migrants who had been selected to receive an EduRemesa offer were divided into three groups: receiving no match offer, a 1:1 match offer, or a 3:1 match offer. This randomization was done at the individual level and was stratified within sequentially-numbered groups of six surveys. All treatment materials were contained in a sealed envelope attached to each survey that was opened by the surveyor when the survey concluded and the treatment began. Surveyors did not know before opening the envelope which match treatment had been assigned. The randomization process is depicted in Online Appendix Figure 1 . The following is a description of the information provided to the different groups. ${ }^{14}$

\section{Control group: Encouragement to send remittances for education}

Migrants in the control group were provided with a handout that discussed the importance of supporting education in El Salvador and suggested sending remittances directly to students in monthly installments. Project staff reviewed the handout with the migrant and gave it to the migrant to take home. The control group was provided with this information to help ensure that any effects found of the EduRemesa could be interpreted as due to the product itself, and not due to the encouragement that it provided for directing remittances towards education or to specific suggestions on how to send remittances for education.

Treatment group 1: EduRemesa with no match (without subsidy)

Migrants in this group were provided with the same information and handout given to the migrants in the control group. Following that discussion, migrants were then introduced to the EduRemesa. Migrants were given a pamphlet that they reviewed with the surveyor that contained all relevant information and contact information for US based project staff and FEPADE in El Salvador.

EduRemesas were available in the fixed amounts of $\$ 300$ or $\$ 500$ for

\footnotetext{
${ }^{14}$ Copies of the materials provided to study participants can be found in Online Appendix A.
} 
secondary school students and $\$ 600$ or $\$ 800$ for tertiary students. ${ }^{15}$ As part of the project, migrants were exempted from paying FEPADE's administrative fees, and they received a coupon with the informational pamphlet that informed them of this. ${ }^{16}$ Migrants who took up the EduRemesa chose the beneficiary student and beneficiaries received an ATM card from FEPADE and one tenth of the amount sent by the migrant would be deposited into their accounts every month during the ten months of the school year. This money was intended to be used by the student for expenses related to their education, but this was not enforced. The purpose of offering the EduRemesa without any subsidy was to analyze the demand for and impact of a product that allowed migrants to directly channel remittance funds toward education.

Treatment group 2: EduRemesa with a 1:1 match

Migrants in this group received the same information as migrants in treatment 1 , but their coupon informed them that in addition to not having to pay the administrative fees, they were being offered a 1:1 match on every dollar sent as part of an EduRemesa. For example, in order to send a \$300 EduRemesa, they would have to provide only \$150 and the project would provide the remaining \$150.

Treatment group 3: EduRemesa with a 3:1 match

This treatment was identical to treatment 2, except that the match rate was 3:1. In order to send a \$300 EduRemesa, migrants would have to pay only $\$ 75$ and the project would provide $\$ 225$. A description of the amount to be sent by the migrant for each treatment and EduRemesa amount is in Online Appendix Table 2.

\footnotetext{
${ }^{15}$ The choice of these fixed amounts was motivated by the amounts offered in the existing scholarship program run by FEPADE. FEPADE designs their scholarships with specific costs in mind and lacks the administrative capacity to implement a larger number of choices. Additionally, it was thought that these discrete options provided a simpler choice for the migrant participants. Ultimately, these concerns outweighed the analytical benefits of allowing migrants free choice for the amount of the EduRemesa.

${ }^{16}$ FEPADE typically charges administrative fees of $15 \%$ of the total amount for their scholarship programs. All migrants, even those in the no match group, were exempted from this administrative fee (the fees were paid with project funds).
} 
In all three treatment groups, the interaction ended by asking the migrants whether or not they were at all interested in the EduRemesa and whether they would like to receive a follow up call from the project. Migrants who indicated that they were interested in sending an EduRemesa filled out a short application indicating the identity of the student beneficiary and were contacted by phone several days later to further discuss their interest and answer any questions. Project staff continued to follow up with all participants until they indicated that they were no longer interested. Migrants also had contact information for staff in the United States and FEPADE in El Salvador.

Migrants who decided to take up the EduRemesa did so by sending the desired amount directly to FEPADE through a money transfer company, Viamericas Corporation, our other collaborating organization. Once FEPADE had received the funds, they contacted the beneficiary student to request a copy of the student's identification card needed to issue their ATM card. Once received, the student went to FEPADE's offices in San Salvador or a regional office in San Miguel to complete the paperwork. Students and their guardians were reimbursed for travel expenses. Students were required to sign a letter acknowledging the amount of their EduRemesa and the rules. The rules required that the students turn in proof of enrollment, that students must attend school, comply with academic requirements, and inform FEPADE if they stopped attending school. ${ }^{17}$

\section{Sample, balance tests, and attrition}

Study participants are migrants from El Salvador recruited in the Washington, DC area, and the target students identified by the migrants. Although migrants could send EduRemesas to any student they wished, all impacts will be measured on the sample of target students in both the control and treatment groups.

\footnotetext{
${ }^{17}$ We also implemented a treatment to test the impact of offering a monitoring mechanism to migrants by giving some migrants the ability to receive a report of student grades after each grading period. This treatment and analysis of its impacts are described in Online Appendix C.
} 
Our "full” sample consists of 991 migrants interviewed at baseline. Of these, 728 target households (the "El Salvador follow-up” sample) completed the El Salvador follow-up survey (73\% completion). Because the main outcomes of interest are collected in the El Salvador follow-up survey, this will be our main sample of interest. We also examine some impacts using the sample of 735 migrants who completed the migrant follow-up survey (the "migrant follow-up sample," 74\% completion). ${ }^{18}$

Amounts for educational expenditures and remittances are derived through a series of questions and imputed (in a few cases) when missing to allow for a consistent sample. Target student education expenditures are reported by the target student. When the target student's report is missing, the adult's report is used, and in the few cases where both are missing the expenditures are imputed. For the total expenditures category, $4.0 \%$ of observations include an adult report for at least one of the categories and $0.8 \%$ include an imputed value for at least one of the categories. Remittance amounts are reported by migrants, and imputed when missing. $19.6 \%$ of observations for overall total remittances are imputed. The substance of the results does not change when dropping imputed observations. Further information about the variable construction for all variables and imputation procedures can be found in Online Appendix B.

Online Appendix Table 3A provides baseline summary statistics for the El Salvador follow-up sample. The migrants are 50\% female, 37 years old on average, and have been in the United States for an average of 11 years. Average annual remittances to the target household are $\$ 2,684$, suggesting that even though an existing remittance relationship was not a requirement, most migrants in our sample

\footnotetext{
${ }^{18}$ All regression results in the paper are similar when performed in a sample that was restricted to those migrant-student pairs where both follow-ups were complete, although precision suffers due to the reduced sample size.
} 
do remit to the target households. ${ }^{19}$ The target students are $53 \%$ female and 18.5 years old on average. They are related to the migrant in a diverse set of ways: $26 \%$ are the migrant's child, $25 \%$ the migrant's sibling, 33\% the migrant's niece or nephew, and $10 \%$ are the migrant's cousin. 92\% of target students are in school at baseline. Online Appendix Tables 3B and 3C provide summary statistics for the full sample and the migrant follow-up sample respectively. No meaningful differences are apparent across the three samples at baseline. Additionally, because migrant participants were recruited at the Salvadoran consulate, a relevant concern is whether or not they are similar to the greater population of Salvadoran migrants. In Online Appendix Table 4 we compare the migrants in our sample to Salvadoranborn, non-US citizens living in the Washington, DC metro area in the 2008-2010 American Community Survey (ACS) three year sample. Across a limited number of basic characteristics the migrants in our sample are comparable to the migrants in the ACS, with the exception that the migrants in our sample have been in the United States for slightly less time on average (11.19 years compared to 12.93 years).

Because this is a randomized experiment, it is important to confirm that the randomization was successful in creating balanced treatment groups. Table 1 examines balance across the treatment groups in the El Salvador follow-up sample using the variables reported in Online Appendix Table 3. Online Appendix Tables 5A and 5B examine balance in the full and migrant follow-up samples. The first four columns report the mean of each variable in the control group and each treatment group. The tables also report the p-values on the F-tests for equality of those means. The samples are well-balanced at baseline. The number of p-values below 0.10 or 0.05 is small and not different from what would be expected given sampling variation.

\footnotetext{
${ }^{19}$ At baseline, $86 \%$ of migrants report sending nonzero remittances to the target household during the past year.
} 
Given the attrition from the full sample to the follow-up samples it is also important to test whether this attrition is related to treatment. Online Appendix Table 6 presents regression estimates of whether survey completion varies in each of the three treatment groups compared to the control group. The table also reports the p-values from tests of the equality of survey completion between the different treatment groups. The dependent variables are completion of the El Salvador follow-up, the migrant follow-up, and both surveys in columns 1,2 , and 3 respectively. The results show that attrition is not related to treatment status.

\section{Empirical results}

\section{A. Estimation}

Random treatment assignment allows us to estimate the causal impact of the different EduRemesa treatments on a variety of outcomes. The main results in this paper are estimated using the following equation:

$$
\begin{aligned}
\text { outcome }_{i j t}= & \beta_{0}+\beta_{1} 3: 1 \text { match }_{i j t}+\beta_{2} 1: 1 \text { match }_{i j t}+\beta_{3} \text { no match }_{i j t}+ \\
& \delta_{j t}+\varepsilon_{i j t} \quad \text { (1) }
\end{aligned}
$$

where $i$ indexes each migrant-target student pair, $j$ the location of the initial interaction with the migrant, and $t$ the week of the initial interaction. $\beta_{1}, \beta_{2}$, and $\beta_{3}$ are the average difference between an outcome variable in the 3:1 match treatment, the 1:1 match treatment, and the no match treatment respectively, and its value in the control group. They are the intent to treat (ITT) effects of the three EduRemesa treatments on the outcomes of interest. $\delta_{j t}$ are stratification cell fixed effects representing the week and location of the observation's baseline survey. There are 28 week-location stratification cells in all analysis samples. Robust standard errors are clustered by unique combinations of day and location of the baseline interaction (the level of the EduRemesa randomization). The main regressions have 125 day-by-location clusters.

\section{B. Take-up}


The first step in our analysis is to examine the take up of the EduRemesa and how that take up differs by treatment. All take-up related variables come from the EduRemesa administrative data, provided by both Viamericas and FEPADE. Panel 1 of Table 2 describes the basic characteristics of the EduRemesas sent. 52 EduRemesas were sent by 41 migrants. 85\% of migrants who sent an EduRemesa (35 out of 41) sent one to the target student they named at baseline. 67\% of EduRemesa recipients were target students (35 out of 52) and most EduRemesas sent to non-target students were from migrants who sent more than one EduRemesa. 40 EduRemesas were sent in the 3:1 match group and 12 were sent in the 1:1 match group. No migrants in the no match treatment group chose to send an EduRemesa.

Panel 2 of Table 2 displays average characteristics of EduRemesas, conditional on the migrant sending at least one EduRemesa. Migrants supported 1.2 students on average in the 1:1 match group and 1.3 students in the 3:1 match group. In the 1:1 and 3:1 groups respectively migrants sent (inclusive of the match) an average of $\$ 690$ and $\$ 719$ in total, $\$ 540$ and $\$ 465$ of which went to target student beneficiaries. Online Appendix Table 7 shows the number of EduRemesas sent by amount of the EduRemesa. Migrants take advantage of the match offer by usually choosing to send the larger available amount. 28 of the 34 EduRemesas sent for secondary schooling were for $\$ 500$, and 13 of the 18 sent for tertiary schooling were for $\$ 800$.

Table 3 estimates the impact of the treatments on take-up using equation (1). The results shown in Table 3 are obtained using the El Salvador follow-up sample and the results of the same analyses in the full and migrant follow-up samples are shown in Online Appendix Tables 8A and 8B. Take-up in both the control group and the no match group is zero. Both the 3:1 and 1:1 match treatments encourage take-up relative to the no-match treatment group and the control group, but the 3:1 match is much more effective. Column 1 examines whether a particular migrant sent any EduRemesa, and column 2 the total number 
of EduRemesas sent. Migrants in the 3:1 match group were 18.5 percentage points more likely to send an EduRemesa at all and those in the 1:1 match group were 6.9 percentage points more likely. The 3:1 group sent 0.25 EduRemesas on average and the 1:1 group sent 0.08. Migrant contributions to EduRemesas average \$23 and \$35 in the 1:1 and 3:1 match groups respectively (column 3). This resulted in an average of \$50 in total EduRemesa funds (migrant contribution plus matching funds) sent from the 1:1 group and $\$ 140$ sent from the 3:1 group (column 4).

Columns 5, 6, and 7 examine EduRemesas sent to target students. The 1:1 match increased the likelihood that an EduRemesa was sent to the target student by 6.0 percentage points; the same figure for the 3:1 match was 15.1 percentage points (column 5). Migrants contributed \$18 and \$22 in the 1:1 and 3:1 match groups (column 6), for average receipts by target students of \$37 and \$86 (column 7).

The take-up results indicate zero demand for the EduRemesa without subsidy via matching funds. The unsubsidized EduRemesa could have been attractive to migrants if they had stronger preferences for educational expenditures than their family members. The existing evidence is mixed on whether migrants desire control over how remittances are used. Ashraf et al. (forthcoming) find that migrants demand control over savings in the home country, but Torero and Viceisza (2013) do not find the same for control over grocery spending (both these studies were also conducted among migrants from El Salvador in the DC metro area). De Arcangelis et al. (2014) find, in an artefactual field experiment in Italy, that Filipino migrants share more resources with family members in the home country when they can label them as intended for education (a "soft" commitment), but offering a "hard" commitment (channeling funds directly to schools) on top of the labeling leads to a much smaller additional increase in remittances.

Zero take-up of the EduRemesa without the matching funds suggests that, in this context, migrants do not seek greater control over remittance uses, at least when it comes to education. However, other aspects of the specific mechanism 
offered may have contributed to zero take-up. In particular, the fact that migrants had to furnish the entire amount of the EduRemesa up front was probably detrimental to take-up (given this is a relatively low-income and likely liquidityconstrained population). It is also possible that migrants did not believe that the product would provide the level of control they desired, since funds were not actually channeled directly to schools or educational expenditures. Other transaction costs such as the need to collect documentation and the opportunity cost of the time spent traveling to the disbursement site may also have impeded take-up.

Despite zero take-up in the no match group, take-up increases monotonically with the match level and suggests a high elasticity of demand for the EduRemesa with respect to the match rate. This finding is consistent with Duflo et al. (2006), who found very low take-up of a savings program (Individual Retirement Accounts, or IRAs) without a match and participation that increased in the match level when a match was offered. ${ }^{20}$

We interpret this result to indicate that the "demand for commitment," in this context, is elastic with respect to subsidies. Our results are consistent with migrants having a demand for channeling remittances to education, but having no demand for the unsubsidized EduRemesa because of transaction costs or liquidity constraints, or because they perceive that the degree of commitment provided by the EduRemesa is limited. The matching funds overcome these costs, leading to positive take-up that monotonically increases in the match rate. ${ }^{21}$

\section{Impact on educational expenditures}

We now turn to the principal question of the paper: how did the EduRemesa

\footnotetext{
${ }^{20}$ It contrasts however, with work on charitable donations that finds that take-up does not increase with the match rate (Karlan and List, 2007).

${ }^{21}$ Another possibility, of course, is that migrants have no demand for commitment, are simply "gaming" the offer to obtain the matching funds, and do not intend to use the funds for education. As it turns out, this appears not to be the case: in Section 4.D below, we show that the EduRemesa treatment does lead to increases in educational expenditures.
} 
affect the education spending of recipients? Although the EduRemesa was specifically marketed and designed as a tool to provide education funds directly to students, because money is fungible it is not obvious that EduRemesa funds would result in an increase in education expenditures. Follow-up data collected from the target students and adults in their households allow us to answer this question.

Table 4 reports impacts on target student education expenditures. Column 1 examines total annualized expenditures on the target student's education and columns 2 through 9 examine expenditures by category. The main result is that the target students in the 3:1 match group spend an average of \$301 more on educational expenses, an increase of $22 \%$ over the control group. As expected given lower take-up, there is a smaller increase in the 1:1 match group, but it is not statistically significant. The overall increase in the 3:1 match group is driven by large increases in tuition (\$106), transportation (\$77), and food (\$143). The only statistically significant increase in the 1:1 match group is for tuition (\$83). Despite zero take-up in the no match group, tuition expenditures increase by $\$ 67$, but this does not translate to an increase in overall education expenditures. ${ }^{22}$

In order to fully understand how the EduRemesa is affecting resources allocated towards education it is instructive to examine total household education expenditures. If household expenditures go up by less than target student expenditures, then the increases documented in Table 4 may be due to shifting of resources away from other students towards the target student. We perform this analysis by summing the reports of expenditures on the target student with the reports of expenditures for others aged 22 or under in the household. ${ }^{23}$ The results

\footnotetext{
${ }^{22}$ These results are shown graphically in Online Appendix Figure 2, which plots the cumulative distribution of total expenditures for the control group and the three treatment groups. The distribution of the 3:1 match group is clearly shifted to the right compared to the control group, the no match group, and the 1:1 match group.

${ }^{23}$ The expenditures on these other students were reported by the adult interviewed in the target household and imputed when missing to maintain a consistent sample. $4.5 \%$ of observations in the total expenditures category include an imputed value for at least one of the categories. Further
} 
are presented in Table 5. The set-up of the table is parallel to Table 4, but all the outcomes are for household-level expenditures.

The results mirror those for target student education expenditures. Expenditures increase overall and this increase is driven by increases in tuition, transportation, and food. However, the estimates on total household expenditures are less precise and not all the impacts are statistically significant. Despite this, the coefficients are similar in magnitude to the coefficients for target student expenditure alone. This indicates that the increases in target student expenditures are not accompanied by reductions in expenditures for other students.

Table 4 shows that the 3:1 match treatment increases total target student education expenditures by $\$ 301$, which should be compared to average target student EduRemesa funds received of \$85 (Table 3, column 7). It appears that education spending increases by the total amount of the EduRemesa, and, additionally that the EduRemesa may actually encourage further investment in education by the target household. In other words, receipt of the EduRemesa may actually be “crowding in” educational expenditure.

To examine this explicitly, column 1 of Table 6 reports the results of an instrumental variables regression estimating the impact of each dollar of EduRemesa funds on target student educational expenditures. Because the large increases in educational expenditures occur just in the 3:1 match group, we utilize only the control group and the 3:1 match group in this analysis. We instrument for total target student receipt of EduRemesa funds with the 3:1 match group treatment indicator and estimate the model by two stage least squares. As in equation (1), the instrumental variables regressions include stratification cell fixed effects and standard errors are clustered at the day-location level. The first stage coefficient is 85.34 and the F-statistic is 28.17, indicating that the instrument is strong according

details are described in Online Appendix B and all results are robust to the exclusion of imputed values. 
to the Stock and Yogo (2005) thresholds.

The estimated coefficient reveals the impact of each dollar of EduRemesa funds on target student educational expenditures. It can be interpreted as a test of crowd-out vs. crowd-in: a coefficient statistically significantly smaller than 1 would reveal crowd-out, while a coefficient statistically significantly larger than 1 would indicate crowd-in. The coefficient is 3.72, indicating that each dollar of EduRemesa funds leads to an increase of \$3.72 in target student education expenditures. This estimate is statistically significantly different from unity at the $10 \%$ level. Because this coefficient exceeds 1 , we refer to it coefficients as a "crowd-in ratio."24

One caveat to the results that we present here is that all of the school expenditure data is self-reported, leaving open concerns about experimenter demand effects (reporting bias that is differential by treatment group). Target students receiving the EduRemesa knew that they were receiving a transfer that was meant to be used for education and may have overstated their educational expenditures as a result. Unfortunately, it was infeasible for us to collect administrative data on expenditures from the wide variety of public and private schools attended by the students and the diverse categories in which expenditures were made. Therefore, we cannot conclusively rule out the possibility that reporting bias contributes to our large estimated effect sizes.

We can point to some evidence that reporting bias is not likely to be the only or the principal driver of our results. First, the increases in expenditures are concentrated in tuition, transport, and food. If target students were inflating their expenditures, it is not clear why they would limit themselves to those three categories, instead of increasing all their reports, or concentrating on categories

\footnotetext{
${ }^{24}$ It should be noted that this crowd-in ratio is estimated using the limited number of discrete amounts offered by the EduRemesa product. One limitation of our design is that we cannot extrapolate what this crowd-in ratio may have been outside of the amounts that we offer as part of this experiment. Larger EduRemesas for example may actually decrease crowd-in as more expenditures are covered by the EduRemesa itself.
} 
more directly linked to education such as books. Additionally, though the EduRemesa was linked to the target student, it is possible that if reporting bias was severe, it would spill over into reports of expenditures on other children. We find no evidence of this, as the impacts on household expenditures (Table 5) are similar to those on target student expenditures (Table 4). However, despite these arguments, absent administrative data we cannot be definitive about the exact magnitude of the impact on expenditures. ${ }^{25}$

\section{Impact on other target student outcomes}

Given the finding of crowd-in it is interesting to examine other elements of the target students' behavior that may be consistent with these increases in expenditure. For example, changes in school enrollment decisions could necessitate large increases in spending that are not fully covered by the EduRemesa. In Table 7, we turn to the impacts on school enrollment and type of school. Column 1 examines whether or not the target student is in school at follow-up and columns 2 through 4 whether the target student is in any private school, parochial school, or non-parochial private school (the latter two are subcategories of private schools).

The treatments do not have statistically significant effects on school enrollment. There is, however, a large impact on the probability that the target student is attending private school. Target students in the 3:1 match group are 11 percentage points more likely to be in private school. This is a large increase relative to the control group private school attendance rate of $27 \%$. These increases in private school attendance concord with the increases in expenditure on tuition and other expenditures discussed above. However, given that private school

\footnotetext{
${ }^{25}$ Another possible interpretation of our expenditure results is that EduRemesa treatment acted to make EduRemesa recipients simply more aware of education related costs and the differences between treatment and control are due to improved reporting by the recipient target students. This explanation would require that target students in the control group are systematically and significantly under-reporting (and not over-reporting) expenditures. While we cannot be sure that this is not happening, we see no compelling reason why under-reporting would be the norm.
} 
attendance also increases in the no match group by a similar amount, it is not clear how large a part the private school effect plays in increasing expenditures.

The concerns related to reporting bias discussed for the expenditure results are also relevant for attendance in private school, particularly given the large size of the effect relative to the control group. In this case we have access to some limited administrative data to verify our survey reports. As a condition of receiving the EduRemesa, all recipients were required to provide FEPADE with proof of enrollment in school before transfers could begin, and FEPADE recorded whether this school was public or private. In the sample of target students in the El Salvador follow-up sample who received an EduRemesa the data indicates that 53\% and 50\% of target students are enrolled in private school, reported in the survey data and the FEPADE data respectively. ${ }^{26}$ These reports are very close, and where they do not agree, the disagreement goes in both directions. It is not only that students who are actually in public school report that they are enrolled in private school. Although this is only a small amount of administrative data and its analysis is not probative, it does not suggest a large amount of reporting bias.

We also examine the impact of the treatments on target students' labor supply. Because the EduRemesa had no effect on overall enrollment, it is not expected that student labor supply would be lower because of decreased drop out, but the receipt of the EduRemesa funds may have reduced the need of the students to work. Increased attendance at private schools may have also required target students to dedicate more time to their studies, reducing their ability to work. However, it is also possible that target students would have had to increase their labor supply, given the large crowd-in of expenditures. We examine the impacts of the match treatments on both the extensive margin (whether a student worked) and

\footnotetext{
${ }^{26}$ This is in contrast to a $27 \%$ private school enrollment rate in the control group. Of course, we do not know the counterfactual enrollment rate for those in the control group who would have received an EduRemesa had they been offered it.
} 
the intensive margin (hours worked per week) in Table 8. We focus here on columns 1 and 2 which examine all work, but also present results for paid and unpaid work separately (columns 3 through 6).

Both the 3:1 and the 1:1 matches had a significant effect on target student labor supply. Students in the 3:1 match group are 14 percentage points less likely to work and work an average of 4.4 fewer hours per week than students in the control group. Students in the 1:1 match group are 7.5 percentage points less likely to work and work 3.2 fewer hours per week. These are large effects: a $64 \%$ reduction in the 3:1 match group compared to the control group. This is evidence of effects on both the extensive and intensive margins. Students in the 3:1 and 1:1 match groups are much less likely to work at all, but they are also less likely to work long hours. ${ }^{27}$

These large reductions in labor supply for target students can be thought of as representing another way in which target students are "spending" their EduRemesa funds, further strengthening the evidence that the EduRemesa leads to crowd-in of resources. To examine this, in column 2 of Table 6 we estimate the impact of total EduRemesa funds received by the target student on the wages earned by the target student, where the EduRemesa funds are instrumented by the 3:1 match group treatment indicator. Because wages are not reported in our survey, we perform an approximation by multiplying the gender- and age-specific mean hourly wage reported in the nationally-representative 2010 Encuesta de Hogares de Propositos Multiples by the number of annual paid hours worked by the target student. This approximation suggests that for every dollar received, target students reduce their earnings by $\$ 1.66$.

\footnotetext{
${ }^{27}$ Online Appendix Figure 3 shows the cumulative distribution of hours worked by treatment. The distributions of both the 3:1 and 1:1 match groups are shifted to the right compared to those of the no match and control groups. The intensive margin is evidenced by the longer tails of the no match and control group distributions
} 
Finally, we can examine the household's contribution to the target student's educational expenditures, net of the target student's earnings. This is shown in column 3 of Table 6 where the dependent variable is total target student education expenditures minus target student estimated earnings. Using the same instrumentation strategy with the addition of the foregone earnings, we find a large crowd-in ratio 5.38. Because of the crude manner in which wages were estimated, strong conclusions should not be drawn from the exact magnitudes of these estimates. We view the results as giving a rough sense of how the estimated crowdin ratio would change when considering the reduction in target student earnings as an additional resource contribution to the target student's education.

\section{E. Impact on remittances}

Having examined how the EduRemesa treatments directly impacted outcomes related to education, it is instructive to consider impacts on remittances sent by the migrant. These remittances were reported by the migrant in the migrant follow-up survey. The survey questions used to calculate total remittances explicitly instructed migrants not to include any funds that were remitted as part of an EduRemesa. Therefore, we analyze the impact of the EduRemesa treatments on all remittances sent by the migrant, except for the funds sent as an EduRemesa.

This analysis is presented in Table 9. The dependent variable of interest is the remittances sent by the migrant between January 1, 2012 and the follow-up survey date to the target household (column 1), to other households in El Salvador (column 2), and to all households (column 3). ${ }^{28}$ Because of several outliers in the remittance data, we also show results that trim the top one percent of values (columns 4-6) and results that utilize the inverse hyperbolic sine transformation of

\footnotetext{
${ }^{28}$ Because the information was reported by the migrant during the migrant follow-up survey, the analysis sample differs slightly from most other analyses in this paper, which are on the El Salvador follow-up survey sample.
} 
the remittance variable (columns 7-9). ${ }^{29,30}$

There is no consistent evidence in Table 9 that the 3:1 match treatment (the treatment with the highest take-up) results in changes in remittances either to the target household or overall. The estimated coefficients are negative, but not statistically significant. An oddity is that in columns 1-3 there appear to be negative effects of the 1:1 and no match treatments. However, these effects are not robust to trimming or to the inverse hyperbolic sine transformation.

The imprecision of the estimated treatment effects on remittances makes it difficult to make strong conclusions. The results in Table 9 are suggestive that total remittances are relatively inelastic with respect to the kind of subsidies we offered in this intervention. Because the dependent variables in Table 9 exclude funds sent via the EduRemesa, negative point estimates on the treatment indicators are consistent with migrants maintaining a relatively constant total resource flow (remittances plus EduRemesa funds) to El Salvador. Indeed, the negative point estimate on the 3:1 match treatment in Table 9, column $1(-167.9)$ is roughly similar in magnitude to the positive point estimate on the 3:1 match treatment in Table 3, column 7 (85.5), which is consistent with migrants reducing remittances to the target household by roughly the match-inclusive EduRemesa amount.

Overall, it appears that the 3:1 match treatment leaves total remittances relatively constant, reduces target student labor supply, and does not reduce educational expenditures on other (non-target) students in the household. Funds for observed increases in educational expenditures on target students must therefore be coming from other sources, such as non-education household consumption or savings.

\footnotetext{
${ }^{29}$ The inverse hyperbolic sine transformation is $\log \left(y_{i}+\left(y_{i}{ }^{2}+1\right)^{1 / 2}\right)$. It can be interpreted in the same way as a logarithmic dependent variable, but does not suffer the same problem of being undefined at zero (Burbidge et al. 1988).

${ }^{30}$ All results in previous tables relating to education expenditures (Tables 4 and 5) are robust to trimming of the top $1 \%$ and the inverse hyperbolic sine transformation.
} 


\section{F. Discussion, additional analyses, and longer term impacts}

Given the long literature exploring differences in education outcomes by gender in developing countries, we examine whether or not the EduRemesa treatments differentially affected male and female students. This analysis is presented in Table 10, where we examine treatment impacts on key outcomes for female target students in Panel 1 and male target students in Panel 2. ${ }^{31}$ The results show that female target students in the 3:1 match group are more likely than male target students to receive an EduRemesa (18\% compared to 11\%) and this translates into larger impacts across most outcome categories for female students. The exception are the labor market outcomes, where the impacts are similar, but this may be due to higher rates of male students working overall. The stronger impacts for female target students are interesting particularly in light of the fact that while a majority of target students are female, they are not overwhelmingly so; $43 \%$ of migrants choose male target students.

We provide some discussion and other analyses of our results in Online Appendix C. We discuss how we rule out marketing effects as the main driver of our results, and also discuss the relative magnitude of the impacts of the 3:1 and the 1:1 matches. We additionally provide analyses showing that an additional treatment that varied whether migrants received official grade reports for the EduRemesa beneficiaries had no statistically identifiable impacts. ${ }^{32}$

In Online Appendix D we present the results of a second follow-up survey conducted roughly one year after the first intended to study the longer-term impacts

\footnotetext{
${ }^{31}$ Online Appendix Tables 9 and 10 show attrition and baseline balance by gender. There is no consistent pattern of differential attrition or baseline imbalance when separating the sample by gender. One exception is that there is lower migrant follow-up survey completion for the 1:1 match treatment in the subsample with male target students. Additionally, there is imbalance between treatment groups for male target students in baseline school enrollment.

${ }^{32}$ In the same sample, using an artefactual field experiment, Ambler (2014) finds that remittance recipients do not alter spending decisions in response to being monitored by the migrant. This suggests that, in this context, recipients are not responsive to migrant monitoring.
} 
of the EduRemesa program. Due to high attrition (46\% completion), we do not discuss these results in the main text of the paper. Many of the results follow the same basic patterns, with the exception of the labor supply results which are no longer present. However, due to the high attrition, small sample sizes do not allow us to draw definitive conclusions.

\section{Conclusions and policy implications}

These results can help guide policies aimed at increasing the development impact of remittances. They indicate that programs subsidizing education in developing countries can extend the resources available to them via contributions from two additional sources: 1) international migrants, who respond positively to matching grant programs for home-country education, and 2) beneficiary households themselves, who respond to subsidies by contributing additional resources. Our estimates indicate that each $\$ 1$ of donor funds provided for secondary or tertiary education can generate additional contributions amounting to \$0.33 from migrants and \$3.62 from beneficiary households themselves. ${ }^{33}$

Our finding of zero take up in the no-match treatment may also reveal that migrants have no or limited unsubsidized demand for control over remittance recipient expenditures on education. Alternatively, transaction costs in this context may exceed migrant willingness to pay for the services, suggesting that policy makers should seek to reduce the administrative burden of such programs.

Beyond the use of matching funds and the payment mechanism, an additional characteristic of the EduRemesa intervention that differentiates it from other programs is the fact that the beneficiaries are chosen by the migrants. Given the magnitude of the effects of the program, it seems that the migrants were successful in selecting students likely to use the subsidy to make large investments

\footnotetext{
33 These figures are implied by the crowd-in ratio of 3.72 (column 1, Table 6): of the increase in expenditures of \$3.72, target student households fund \$2.72, while the EduRemesa funds \$1 (of which $\$ 0.75$ is donor-funded and $\$ 0.25$ is migrant-funded).
} 
in their education. In other words, although take-up was low, utilizing migrants to screen recipients was effective in directing the program towards students who would benefit. This result suggests that requiring contributions from family members can do more than simply alleviate the financial burden of such educational transfer programs, but can also serve to target those transfer programs towards students who will benefit even with only minimal oversight.

Our results are, of course, limited to the context that we study, and so it is not known whether self-screening by program participants would be as effective in other situations, for example if the product was offered to a general household population in a developing country without international migrant members. Relatedly, transnational households may respond differently to the offer of an EduRemesa-like product, because they self-selected into migration and may have characteristics also associated with higher demand for long-term household investments (such as education). Therefore, it is important to replicate this study in other populations and contexts to gauge the generalizability of these results.

\section{References}

Afridi, Farzana (2010). "Child Welfare Programs and Child Nutrition: Evidence from a Mandated School Meal Program in India," Journal of Development Economics, 92, 152-65.

Angelucci, Manuela and Orazio Attanasio (2009). "Program Effect on Consumption, Low Participation, and Methodological Issues," Economic Development and Cultural Change, 57(3).

Angelucci, Manuela and Giacomo De Giorgi (2009). "Indirect Effects of an Aid Program: How do Cash Transfers Affect Ineligibles' Consumption?” The American Economic Review, 99(1), 486-508.

Angelucci, Manuela, Giacomo de Giorgi, Marcos Rangel, and Imran Rasul (2010). "Family Networks and School Enrolment: Evidence from a Randomized Social Experiment," Journal of Public Economics, 94(3-4), 197-221.

Angrist, Joshua, Eric Bettinger, Erik Bloom, Elizabeth King, and Michael Kremer (2002). "Vouchers for Private Schooling in Colombia: Evidence from a Randomized Natural Experiment," American Economic Review, 92(5), 153558. 
Ambler, Kate (2014). “Don’t Tell on Me: Experimental Evidence of Asymmetric Information in Transnational Households,” mimeo, IFPRI.

Ashraf, Nava, Diego Aycinena, Claudia Martinez, and Dean Yang (forthcoming). "Savings in Transnational Households: A Field Experiment Among Migrants from El Salvador,” Review of Economics and Statistics.

Baird, Sarah, Craig McIntosh, and Berk Ozler (2011). "Cash or Condition? Evidence from a Cash Transfer Experiment," The Quarterly Journal of Economics, 126, 1709-53.

Barrera-Osorio, F., M. Bertrand, L. Linden, and F. Perez-Calle (2011). “Improving the Design of Conditional Transfer Programs: Evidence from a Randomized Education Experiment in Colombia," American Economic Journal: Applied Economics, 3, 167-95.

Behrman, Jere R., Piyali Sengupta, and Petra Todd (2005). "Progressing through Progresa: An Impact Assessment of a School Subsidy Experiment in Rural Mexico,” Economic Development and Cultural Change, 54(1), 237-75.

Benhassine, Najy, Florencia Devoto, Esther Duflo, Pascaline Dupas, and Victor Pouliquen, “Turning a Shove into a Nudge? A 'Labeled Cash Transfer' for Education,” NBER Working Paper 19227, July 2013.

Burbidge, John B., Lonnie Magee, and A Leslie Robb (1988). "Alternative Transformations to Handle Extreme Values of the Dependent Variable," Journal of the American Statistical Association, 83(401), 123-27.

Carneiro, Pedro, Andrea Locatelli, Tewolde Ghebremeskel and Joseph Keating (2012). "Do Public Health Interventions Crowd Out Private Health Investments? Malaria Control Policies in Eritrea,” working paper, University College London.

Clemens, Michael (2011). "Economics and emigration: Trillion-dollar bills on the sidewalk?” Journal of Economic Perspectives, 25 (3): 83-106.

Clemens, Michael A., Claudio E. Montenegro, and Lant Pritchett (2009). "The Place Premium: Wage Differences for Identical Workers Across the U.S. Border,” Center for Global Development Working Paper 148.

Cox Edwards, Alejandra and Manuelita Ureta (2003). “International Migration, Remittances, and Schooling: Evidence from El Salvador," Journal of Development Economics, 72(2), 429-61.

Das, Jishnu, Stefan Dercon, James Habyarimana, Pramila Krishnan, Karthik Muralidharan, and Venkatesh Sundararaman (2013). "School Inputs, Household Substitution, and Test Scores," American Economic Journal: 
Applied Economics, vol. 5(2), April, 29-57.

De Arcangelis, Giuseppe, Majlinda Joxhe, David McKenzie, Erwin Tiongson, and Dean Yang (2014), "Directing Remittances to Education with Soft and Hard Commitments: Evidence from a Lab-in-the-field Experiment and New Product Take-up Among Filipino Migrants in Rome,” working paper.

De Brauw, Alan and Daniel Gilligan (2011). "Using the Regression Discontinuity Design with Implicit Partitions: The Impacts of Comunidades Solidarias Rurales on Schooling in El Salvador,” IFPRI Discussion Paper 01116.

Duflo, Esther and Christopher Udry (2004). "Intrahousehold Resource Allocation in Cote D'Ivoire: Social Norms, Separate Accounts and Consumption Choices,” NBER Working Paper 10498.

Duflo, Esther, William Gale, Jeffrey Liebman, Peter Orszag, and Emmanuel Saez. "Saving incentives for low-and middle-income families: Evidence from a field experiment with H\&R Block." Quarterly Journal of Economics 121.4 (2006): 1311-1346.

Edmonds, Eric V. and Norbert Schady (2012). "Poverty Alleviation and Child Labor,” American Economic Journal: Economic Policy, 4(4), 100-124.

Fizbein, Ariel and Norbert Schady with Francisco Ferreira, Margaret Grosh, Niall Kelleher, Pedro Olinto, and Emmanuel Skoufias (2009). Conditional Cash Transfers: Reducing Present and Future Poverty. Washington, DC: The World Bank.

FUSADES (2011). “Tendencias en Educación,” Informe de Coyuntura Social.

Glewwe, Paul and Ana Lucia Kassouf (2012). "The Impact of Bolsa Escola/Familia Conditional Cash Transfer Program on Enrollment, Dropout Rates, and Grade Promotion in Brazil,” Journal of Development Economics, 97, 505-17.

Hazan, Miryam (2012). "Beyond 3x1: Linking Sending and Receiving Societies in the Development Process," International Migration, doi:10.1111/j.14682435.2012.00784.x

Hoddinott, John and Emmanuel Skoufias (2004). "The Impact of PROGRESA on Food Consumption," Economic Development and Cultural Change, 53(1), 3761.

Islam, Mahnaz and John Hoddinott (2009). "Evidence of Intrahousehold Flypaper Effects from a Nutrition Intervention in Rural Guatemala," Economic Development and Cultural Change, 57(2), 215-38.

Jacoby, Hanan (2002). “Is There an Intrahousehold 'Flypaper Effect’? Evidence 
from a School Feeding Programme,” The Economic Journal, 112(476), 196221.

Karlan, Dean, and John List. (2007). Does price matter in charitable giving? Evidence from a large-scale natural field experiment. The American Economic Review, 1774-1793.

OECD Aid Statistics (2013). http://www.oecd.org/dac/stats/data.htm

Payne, A. Abigail (2009). "Does Government Funding Change Behavior? An Empircal Analysis of Crowd-Out," NBER Tax Policy and the Economy, 23, 159-84.

Peltzman, Sam (1993). "The Effect of Government Subsidies-in-Kind on Private Expenditures: The Case of Higher Education,” Journal of Political Economy, (81)1, 1-27.

Pew Hispanic Center (2002). Billions in Motion: Latino Immigrants, Remittances, and Banking. Washington, DC: Pew Hispanic Center and Multilateral Investment Fund, 2002.

Schultz, T. Paul (2004). "School Subsidies for the Poor: Evaluating the Mexican Progresa Program,” Journal of Development Economics, 74, 199-250.

Shi, Xinzheng (2012). "Does an Intra-household Flypaper Effect Exist? Evidence from the Educational Fee Reduction Reform in Rural China," Journal of Development Economics, 99, 459-73.

Stock, James, and Yogo, Motohiro (2005). “Testing for weak instruments in linear IV regression,” in Identification and Inference in Econometric Models: Essays in Honor of Thomas J. Rothenberg, ed. D. Andrews and J. Stock.

Terry, Donald and Steven Wilson, eds., (2005). Beyond Small Change: Making Migrant Remittances Count. Washington, DC: Inter-American Development Bank.

Theoharides, Caroline (2014), “Manila to Malaysia, Quezon to Qatar: International Migration and the Effects on Origin-Country Human Capital,” working paper, University of Michigan.

Torero, Maximo, and Angelino Viceisza (2013). “To Remit or Not to Remit: That is the Question. A Remittance Field Experiment,” Working paper, IFPRI.

World Bank (2006). Global Economic Prospects 2006: Economic Implications of Remittances and Migration. Washington, DC.

World Bank (2007). Close to Home: The Development Impact of Remittances in Latin America. Washington, DC. 
World Bank (2012). Migration and Development Brief 19, Migration and Remittances Unit, Washington D.C.

Yang, Dean (2008). "International Migration, Remittances and Household Investment: Evidence from Philippine Migrants' Exchange Rate Shocks,” The Economic Journal, 118(528).

Yang, Dean (2011). “Migrant Remittances,” Journal of Economic Perspectives, 25(3), 129-152. 
Table 1: Baseline balance

\begin{tabular}{|c|c|c|c|c|c|c|c|c|c|}
\hline & \multicolumn{4}{|c|}{ Means } & \multicolumn{4}{|c|}{$P$-values } & \multirow[b]{2}{*}{$N$} \\
\hline & Control & No match & 1:1 match & 3:1 match & $\begin{array}{c}\mathrm{C}=\mathrm{NM}= \\
1: 1=3: 1\end{array}$ & $\mathrm{C}=\mathrm{NM}$ & $C=1: 1$ & $C=3: 1$ & \\
\hline Migrant is female & 0.47 & 0.49 & 0.53 & 0.53 & 0.239 & 0.551 & 0.116 & 0.104 & 728 \\
\hline Migrant age & 36.76 & 36.84 & 36.83 & 37.16 & 0.995 & 0.923 & 0.883 & 0.799 & 709 \\
\hline Migrant is married & 0.60 & 0.55 & 0.68 & 0.59 & 0.168 & 0.180 & 0.187 & 0.914 & 724 \\
\hline Migrant hh size in US & 4.55 & 4.50 & 4.41 & 4.39 & 0.705 & 0.988 & 0.304 & 0.611 & 728 \\
\hline Migrant years of education & 9.14 & 8.78 & 8.74 & 9.80 & 0.207 & 0.450 & 0.534 & 0.217 & 717 \\
\hline Migrant years in US & 10.90 & 11.24 & 11.09 & 11.88 & 0.492 & 0.447 & 0.649 & 0.141 & 726 \\
\hline Migrant annual remittance to target hh (USD) & 2,964 & 2,582 & 2,408 & 2,556 & 0.586 & 0.396 & 0.167 & 0.395 & 713 \\
\hline Migrant annual remittances to other hhs (USD) & 1,248 & 1,054 & 1,031 & 1,342 & 0.515 & 0.380 & 0.327 & 0.577 & 721 \\
\hline Target student is female & 0.57 & 0.55 & 0.50 & 0.48 & 0.281 & 0.928 & 0.190 & 0.139 & 728 \\
\hline Target student age & 18.34 & 18.44 & 18.68 & 18.69 & 0.524 & 0.394 & 0.254 & 0.160 & 713 \\
\hline \multicolumn{10}{|l|}{ Target student is migrant's... } \\
\hline ...child & 0.27 & 0.22 & 0.27 & 0.26 & 0.515 & 0.158 & 0.812 & 0.608 & 727 \\
\hline ...sibling & 0.23 & 0.31 & 0.22 & 0.25 & 0.147 & 0.037 & 0.699 & 0.453 & 727 \\
\hline ...niece/nephew & 0.30 & 0.33 & 0.39 & 0.33 & 0.233 & 0.517 & 0.043 & 0.574 & 727 \\
\hline ...cousin & 0.12 & 0.12 & 0.08 & 0.09 & 0.427 & 0.841 & 0.236 & 0.465 & 727 \\
\hline Target student is in school & 0.92 & 0.90 & 0.93 & 0.94 & 0.562 & 0.369 & 0.740 & 0.549 & 728 \\
\hline Target student years of education & 11.79 & 11.51 & 12.04 & 11.91 & 0.337 & 0.416 & 0.261 & 0.486 & 678 \\
\hline
\end{tabular}


Table 2: Summary of EduRemesa take up

\begin{tabular}{|c|c|c|c|c|}
\hline & No match & 1:1 match & 3:1 match & Total \\
\hline \multicolumn{5}{|l|}{ Panel 1: Characteristics of EduRemesas sent by treatment group } \\
\hline Number of migrants sending ERs & 0 & 10 & 31 & 41 \\
\hline Number of target students receiving ERs & 0 & 9 & 26 & 35 \\
\hline Total number of ERs & 0 & 12 & 40 & 52 \\
\hline ERs sent to other students & 0 & 3 & 14 & 17 \\
\hline \multicolumn{5}{|l|}{ Panel 2: Average characteristics of EduRemesas conditional on takeup } \\
\hline Number of EduRemesas sent & & 1.20 & 1.29 & 1.27 \\
\hline Total EduRemesa amount sent by migrant & & $\$ 332$ & $\$ 180$ & $\$ 217$ \\
\hline Total EduRemesa amount sent by migrant plus matching funds & & $\$ 690$ & $\$ 719$ & $\$ 712$ \\
\hline EduRemesa amount sent by migrant to target student & & $\$ 270$ & $\$ 116$ & $\$ 154$ \\
\hline EduRemesa amount sent by migrant to target student plus matching funds & & $\$ 540$ & $\$ 465$ & $\$ 483$ \\
\hline
\end{tabular}

Notes: Data comes from EduRemesas administrative data. Sample is all migrant-student pairs interviewed at baseline. All money amounts are in US dollars. 
Table 3: Takeup of EduRemesa by treatment

\begin{tabular}{|c|c|c|c|c|c|c|c|}
\hline & $\begin{array}{c}\text { EduRemesa } \\
\text { sent }\end{array}$ & $\begin{array}{c}\text { Number of } \\
\text { EduRemesas } \\
\text { sent }\end{array}$ & $\begin{array}{c}\text { Total } \\
\text { EduRemesa } \\
\text { amount sent by } \\
\text { migrant }\end{array}$ & $\begin{array}{c}\text { (4) } \\
\text { Total } \\
\text { EduRemesa } \\
\text { amount sent by } \\
\text { migrant plus } \\
\text { matching } \\
\text { funds }\end{array}$ & $\begin{array}{c}\text { EduRemesa } \\
\text { sent to target } \\
\text { student }\end{array}$ & $\begin{array}{c}\text { (6) } \\
\text { Total } \\
\text { EduRemesa } \\
\text { amount sent by } \\
\text { migrant to } \\
\text { target student }\end{array}$ & $\begin{array}{c}\text { (7) } \\
\text { Total } \\
\text { EduRemesa } \\
\text { amount sent by } \\
\text { migrant to } \\
\text { target student } \\
\text { plus matching } \\
\text { funds }\end{array}$ \\
\hline 3:1 match & $\begin{array}{c}0.185^{* * *} \\
{[0.0332]}\end{array}$ & $\begin{array}{c}0.248 * * * \\
{[0.0492]}\end{array}$ & $\begin{array}{c}35.09 * * * \\
{[6.984]}\end{array}$ & $\begin{array}{c}139.8 * * * \\
{[27.47]}\end{array}$ & $\begin{array}{c}0.151^{* * *} \\
{[0.0291]}\end{array}$ & $\begin{array}{c}21.61^{* * *} \\
{[4.236]}\end{array}$ & $\begin{array}{c}85.51^{* * *} \\
{[16.25]}\end{array}$ \\
\hline 1:1 match & $\begin{array}{c}0.0686^{* * *} \\
{[0.0201]}\end{array}$ & $\begin{array}{c}0.0841 * * * \\
{[0.0256]}\end{array}$ & $\begin{array}{c}23.14 * * * \\
{[7.107]}\end{array}$ & $\begin{array}{c}49.63 * * * \\
{[15.29]}\end{array}$ & $\begin{array}{c}0.0600^{* * *} \\
{[0.0190]}\end{array}$ & $\begin{array}{c}18.49 * * * \\
{[5.934]}\end{array}$ & $\begin{array}{c}37.15^{* * *} \\
{[12.18]}\end{array}$ \\
\hline No match & $\begin{array}{l}-0.000367 \\
{[0.00985]}\end{array}$ & $\begin{array}{c}0.00532 \\
{[0.0129]}\end{array}$ & $\begin{array}{c}1.184 \\
{[2.445]}\end{array}$ & $\begin{array}{c}4.544 \\
{[7.153]}\end{array}$ & $\begin{array}{l}-0.000529 \\
{[0.00931]}\end{array}$ & $\begin{array}{c}0.559 \\
{[1.879]}\end{array}$ & $\begin{array}{c}1.311 \\
{[4.991]}\end{array}$ \\
\hline \multicolumn{8}{|c|}{$P$-values for tests of equality of coefficients } \\
\hline $3: 1=1: 1$ & 0.002 & 0.004 & 0.246 & 0.005 & 0.011 & 0.667 & 0.021 \\
\hline $3: 1=$ No match & 0.000 & 0.000 & 0.000 & 0.000 & 0.000 & 0.000 & 0.000 \\
\hline $1: 1=$ No match & 0.001 & 0.004 & 0.003 & 0.004 & 0.002 & 0.002 & 0.002 \\
\hline $3: 1=1: 1=$ No match & 0.000 & 0.000 & 0.000 & 0.000 & 0.000 & 0.000 & 0.000 \\
\hline Observations & 728 & 728 & 728 & 728 & 728 & 728 & 728 \\
\hline R-squared & 0.133 & 0.114 & 0.080 & 0.102 & 0.114 & 0.075 & 0.097 \\
\hline Control group mean & 0 & 0 & 0 & 0 & 0 & 0 & 0 \\
\hline
\end{tabular}


Table 4: Target student education expenditures

\begin{tabular}{|c|c|c|c|c|c|c|c|c|c|}
\hline & (1) & (2) & (3) & (4) & (5) & (6) & (7) & (8) & (9) \\
\hline & & & pendent $v$ & able: Annuc & ed target & dent expend & re (USD) & & \\
\hline & Total & Tuition & $\begin{array}{c}\text { School } \\
\text { supplies }\end{array}$ & Uniforms & Books & Transport & Food & $\begin{array}{l}\text { Computer } \\
\text { use }\end{array}$ & Other \\
\hline 3:1 match & $301.5 * *$ & $105.8 * * *$ & -3.343 & 6.962 & 7.323 & $76.67 * *$ & $143.5^{* *}$ & 0.0542 & -35.49 \\
\hline & [125.5] & [32.52] & [7.791] & [6.069] & [7.797] & {$[37.81]$} & [57.33] & [26.29] & [28.62] \\
\hline 1:1 match & 74.97 & $83.38 * *$ & -11.28 & $-8.662 *$ & 5.047 & 35.85 & 48.37 & -29.75 & -47.98 \\
\hline & [117.0] & [32.89] & [7.079] & [4.784] & [7.913] & [41.41] & [51.78] & [25.04] & [34.29] \\
\hline No match & 19.32 & $66.58^{*}$ & -1.105 & -7.527 & $-11.26^{*}$ & 1.060 & 35.94 & -20.00 & -44.37 \\
\hline & [111.5] & [34.93] & [7.508] & [4.815] & {$[5.802]$} & [31.04] & [47.20] & [25.29] & [28.77] \\
\hline$P$-values for tests of ec & ity of coeff & ents & & & & & & & \\
\hline $3: 1=1: 1$ & 0.102 & 0.603 & 0.338 & 0.007 & 0.830 & 0.391 & 0.123 & 0.302 & 0.605 \\
\hline 3:1 = No match & 0.060 & 0.405 & 0.818 & 0.010 & 0.029 & 0.075 & 0.102 & 0.502 & 0.613 \\
\hline 1:1 = No match & 0.675 & 0.691 & 0.270 & 0.811 & 0.053 & 0.406 & 0.840 & 0.765 & 0.869 \\
\hline $3: 1=1: 1=$ No match & 0.136 & 0.705 & 0.459 & 0.014 & 0.029 & 0.200 & 0.191 & 0.560 & 0.838 \\
\hline Observations & 728 & 728 & 728 & 728 & 728 & 728 & 728 & 728 & 728 \\
\hline R-squared & 0.033 & 0.052 & 0.032 & 0.052 & 0.033 & 0.042 & 0.045 & 0.037 & 0.051 \\
\hline Control group mean & 1358 & 187 & 60 & 36 & 55 & 270 & 443 & 218 & 90 \\
\hline
\end{tabular}

Notes: Robust standard errors clustered at the level of the day and location of the baseline survey in brackets. There are 125 dayXlocation clusters in each regression. Sample is all migrant-student pairs with completed El Salvador follow-up surveys. All regressions include stratification cell fixed effects for the week and location of the baseline survey. All money amounts are in US dollars.

${ }^{* * *} \mathrm{p}<0.01,{ }^{* *} \mathrm{p}<0.05,{ }^{*} \mathrm{p}<0.1$ 
Table 5: Total household education expenditures

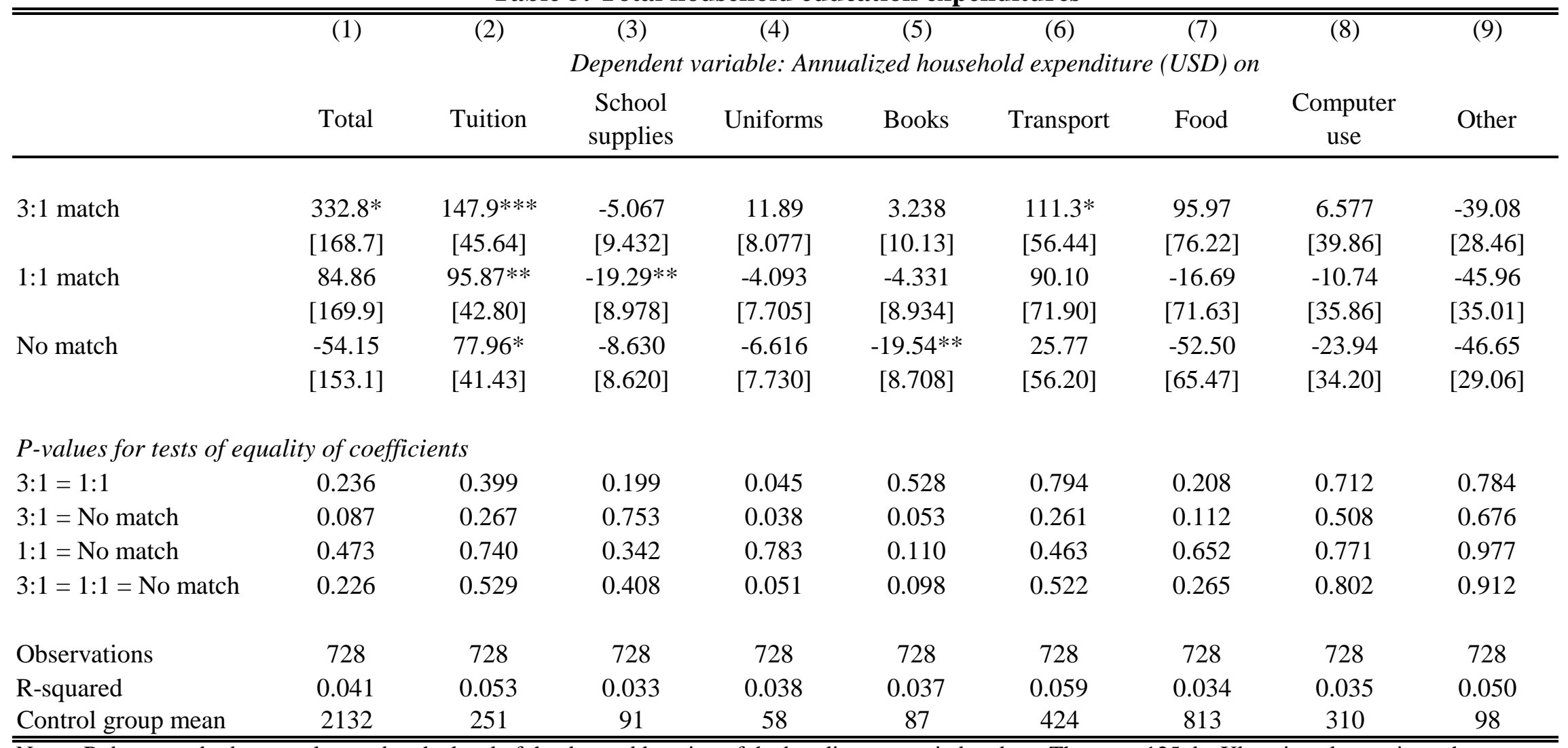

Notes: Robust standard errors clustered at the level of the day and location of the baseline survey in brackets. There are 125 dayXlocation clusters in each regression. Sample is all migrant-student pairs with completed El Salvador follow-up surveys. All regressions include stratification cell fixed effects for the week and location of the baseline survey. All money amounts are in US dollars.

$* * * \mathrm{p}<0.01, * * \mathrm{p}<0.05, * \mathrm{p}<0.1$ 
Table 6: Instrumental variables regressions

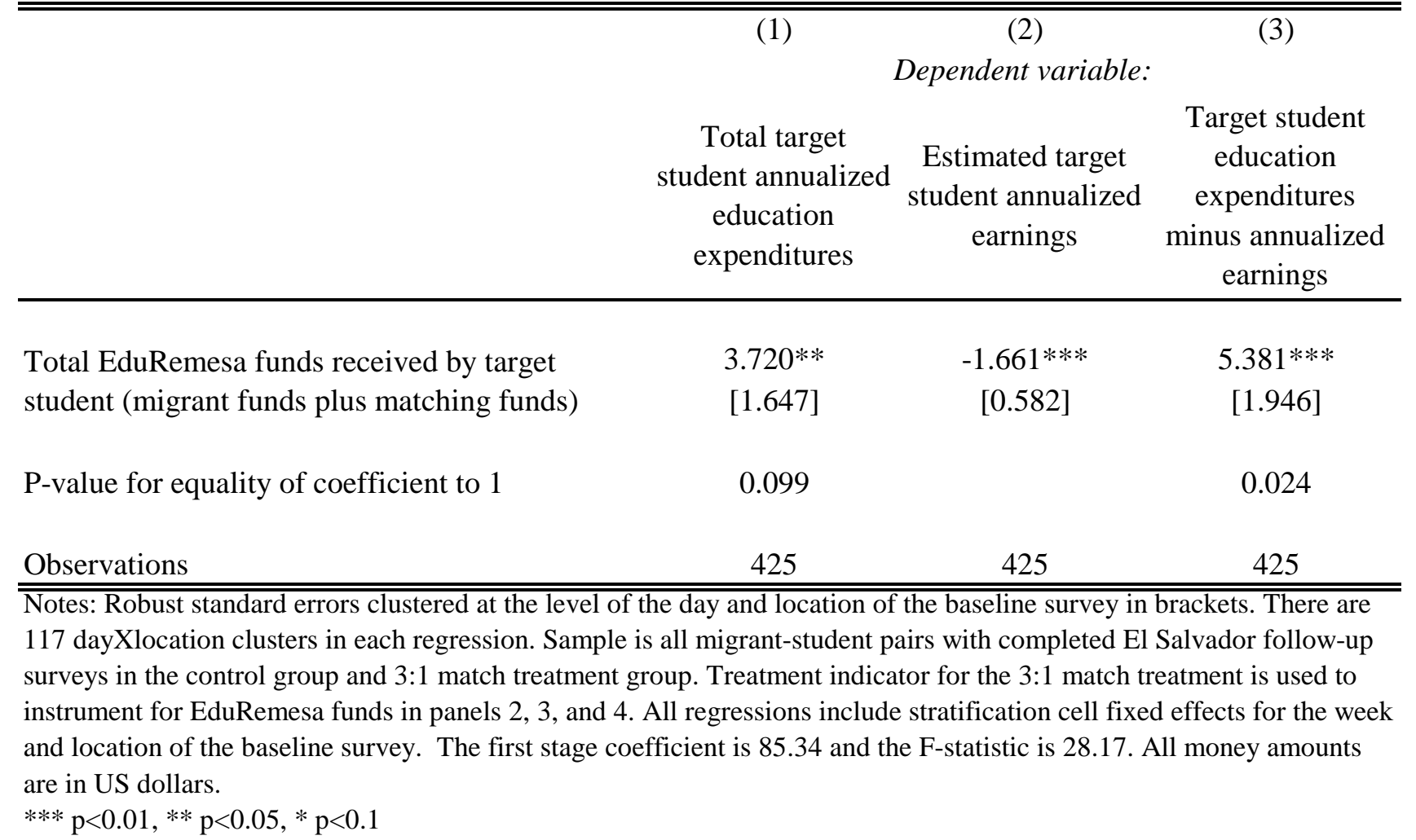




\begin{tabular}{|c|c|c|c|c|}
\hline & (1) & $(2)$ & (3) & $(4)$ \\
\hline & $\begin{array}{l}\text { Target student } \\
\text { is in school }\end{array}$ & $\begin{array}{l}\text { Target student } \\
\text { is in any } \\
\text { private school }\end{array}$ & $\begin{array}{c}\text { Target student } \\
\text { is in parochial } \\
\text { school }\end{array}$ & $\begin{array}{l}\text { Target student } \\
\text { is in other } \\
\text { private school }\end{array}$ \\
\hline \multirow[t]{2}{*}{$3: 1$ match } & 0.0309 & $0.109 * *$ & 0.0288 & $0.0803 * *$ \\
\hline & {$[0.0398]$} & {$[0.0430]$} & {$[0.0375]$} & {$[0.0350]$} \\
\hline \multirow[t]{2}{*}{ 1:1 match } & -0.0210 & 0.0498 & -0.0172 & $0.0671 *$ \\
\hline & {$[0.0381]$} & {$[0.0419]$} & {$[0.0368]$} & {$[0.0346]$} \\
\hline \multirow[t]{2}{*}{ No match } & 0.0182 & $0.0910 * *$ & 0.0298 & 0.0612 \\
\hline & {$[0.0440]$} & {$[0.0460]$} & {$[0.0359]$} & {$[0.0379]$} \\
\hline \multicolumn{5}{|c|}{$P$-values for tests of equality of coefficients } \\
\hline $3: 1=1: 1$ & 0.244 & 0.247 & 0.339 & 0.780 \\
\hline 3:1 = No match & 0.819 & 0.766 & 0.984 & 0.705 \\
\hline $1: 1=$ No match & 0.426 & 0.413 & 0.283 & 0.898 \\
\hline $3: 1=1: 1=$ No match & 0.453 & 0.448 & 0.486 & 0.928 \\
\hline Observations & 728 & 728 & 728 & 728 \\
\hline R-squared & 0.048 & 0.042 & 0.031 & 0.044 \\
\hline Control group mean & 0.74 & 0.27 & 0.16 & 0.11 \\
\hline
\end{tabular}

Notes: Robust standard errors clustered at the level of the day and location of the baseline survey in brackets. There are 125 dayXlocation clusters in each regression. Sample is all

migrant-student pairs with completed El Salvador follow-up surveys. All regressions include stratification cell fixed effects for the week and location of the baseline survey.

*** $\mathrm{p}<0.01, * * \mathrm{p}<0.05, * \mathrm{p}<0.1$ 
Table 8: Target student labor supply outcomes

\begin{tabular}{|c|c|c|c|c|c|c|}
\hline & $(1)$ & $(2)$ & (3) & $(4)$ & $(5)$ & $(6)$ \\
\hline & \multicolumn{6}{|c|}{ Dependent variables refer to work currently being done by the target student } \\
\hline & Any work & $\begin{array}{c}\text { Average hours } \\
\text { per week any } \\
\text { work }\end{array}$ & Paid work & $\begin{array}{c}\text { Average hours } \\
\text { per week paid } \\
\text { work }\end{array}$ & Unpaid work & $\begin{array}{c}\text { Average hours } \\
\text { per week } \\
\text { unpaid work }\end{array}$ \\
\hline \multirow[t]{2}{*}{$1: 1$ match } & $-0.0751 *$ & $-3.204^{* * *}$ & -0.0543 & $-1.780 *$ & -0.0435 & $-1.425 * * *$ \\
\hline & {$[0.0412]$} & {$[1.095]$} & {$[0.0346]$} & {$[0.968]$} & {$[0.0325]$} & [0.431] \\
\hline No match & 0.00897 & -0.386 & -0.0147 & -0.138 & 0.00231 & -0.248 \\
\hline $3: 1=1: 1$ & 0.187 & 0.251 & 0.663 & 0.230 & 0.267 & 0.974 \\
\hline $3: 1=$ No match & 0.006 & 0.003 & 0.163 & 0.022 & 0.021 & 0.010 \\
\hline $1: 1=$ No match & 0.091 & 0.017 & 0.290 & 0.148 & 0.241 & 0.015 \\
\hline $3: 1=1: 1=$ No match & 0.023 & 0.009 & 0.340 & 0.071 & 0.067 & 0.025 \\
\hline Observations & 728 & 728 & 728 & 728 & 728 & 728 \\
\hline R-squared & 0.041 & 0.056 & 0.032 & 0.048 & 0.041 & 0.059 \\
\hline Control group mean & 0.33 & 6.78 & 0.20 & 4.43 & 0.17 & 2.35 \\
\hline
\end{tabular}

Notes: Robust standard errors clustered at the level of the day and location of the baseline survey in brackets. There are 125 dayXlocation clusters in each regression. Sample is all migrant-student pairs with completed El Salvador follow-up surveys. All regressions include stratification cell fixed effects for the week and location of the baseline survey.

$* * * \mathrm{p}<0.01, * * \mathrm{p}<0.05, * \mathrm{p}<0.1$ 
Table 9: Non-EduRemesa remittances sent by migrant

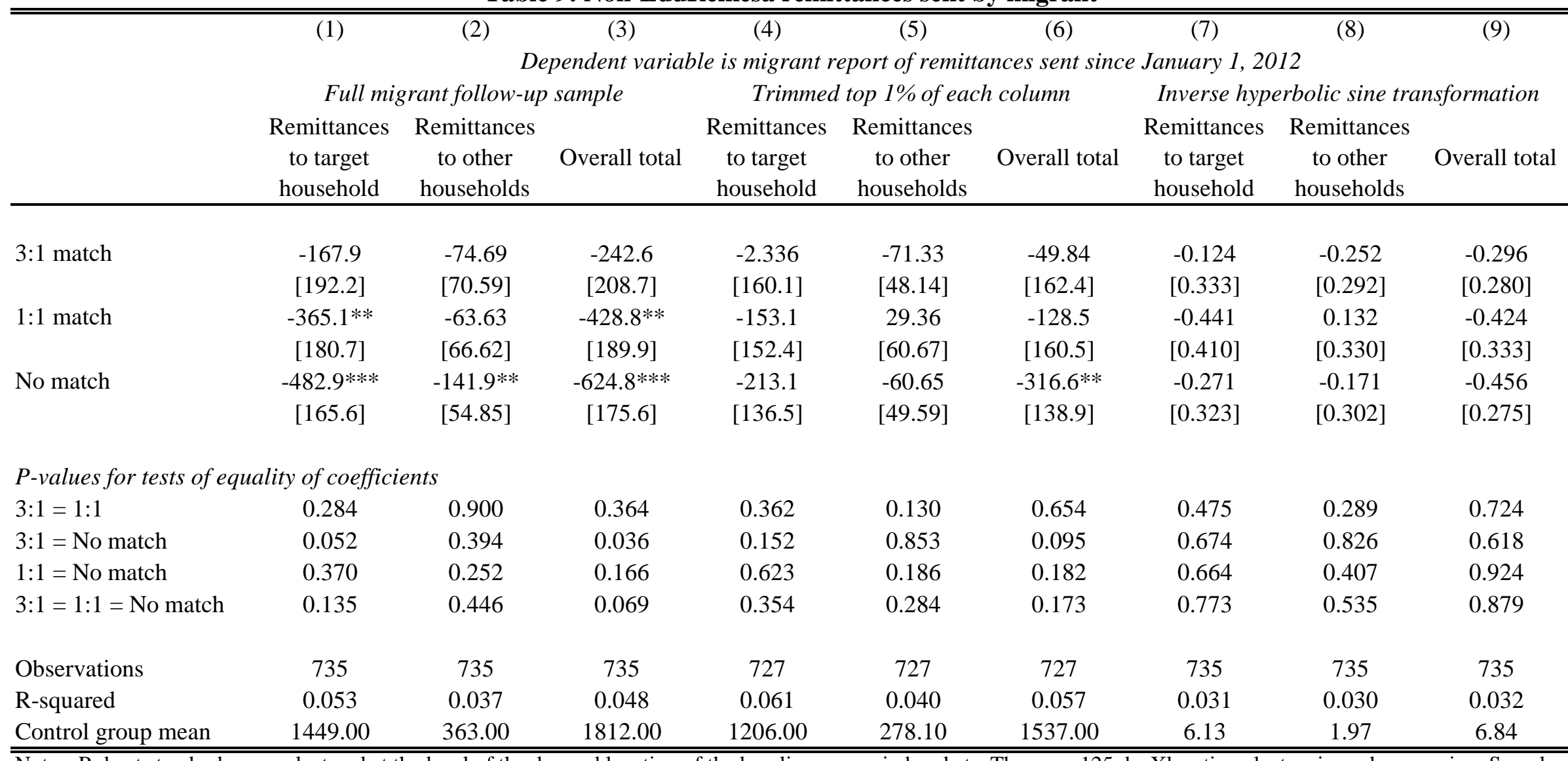

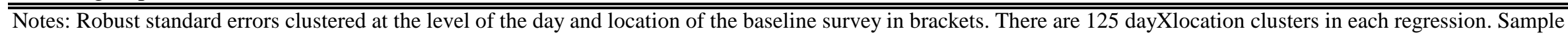

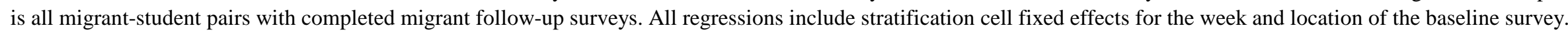
Remittance amounts do not include EduRemesa funds. All money amounts are in US dollars.

$* * * \mathrm{p}<0.01, * * \mathrm{p}<0.05, * \mathrm{p}<0.1$ 
Table 10: Results by target student gender

\begin{tabular}{|c|c|c|c|c|c|c|c|c|}
\hline & (1) & $(2)$ & & $(4)$ & (5) & (6) & (7) & (8) \\
\hline & \multicolumn{2}{|c|}{ Takeup } & \multicolumn{2}{|c|}{$\begin{array}{c}\text { Annualized education } \\
\text { expenditures }\end{array}$} & \multicolumn{2}{|c|}{ Education outcomes } & \multicolumn{2}{|c|}{ Labor supply } \\
\hline & $\begin{array}{l}\text { EduRemesa } \\
\text { sent to target } \\
\text { student }\end{array}$ & $\begin{array}{c}\text { Total } \\
\text { EduRemesa } \\
\text { amount sent by } \\
\text { migrant to } \\
\text { target student } \\
\text { plus matching } \\
\text { funds }\end{array}$ & $\begin{array}{l}\text { Total target } \\
\text { student } \\
\text { expenditures }\end{array}$ & $\begin{array}{c}\text { Total } \\
\text { household } \\
\text { expenditures }\end{array}$ & $\begin{array}{l}\text { Target student } \\
\text { is in school }\end{array}$ & $\begin{array}{l}\text { Target student } \\
\text { is in any } \\
\text { private school }\end{array}$ & Any work & $\begin{array}{c}\text { Average hours } \\
\text { per week any } \\
\text { work }\end{array}$ \\
\hline \multicolumn{9}{|c|}{ Panel 1: Female target students } \\
\hline 3:1 match & $\begin{array}{l}0.178^{* * *} \\
{[0.0464]}\end{array}$ & $\begin{array}{c}108.4^{* * *} \\
{[27.21]}\end{array}$ & $\begin{array}{c}509.4^{* * *} \\
{[183.8]}\end{array}$ & $\begin{array}{l}534.0 * * \\
{[262.0]}\end{array}$ & $\begin{array}{c}0.0836 \\
{[0.0599]}\end{array}$ & $\begin{array}{c}0.183^{* * *} \\
{[0.0619]}\end{array}$ & $\begin{array}{c}-0.157 * * * \\
{[0.0481]}\end{array}$ & $\begin{array}{c}-3.260 * * * \\
{[1.155]}\end{array}$ \\
\hline 1:1 match & $\begin{array}{l}0.101^{* * *} \\
{[0.0346]}\end{array}$ & $\begin{array}{c}59.89 * * * \\
{[21.93]}\end{array}$ & $\begin{array}{c}45.60 \\
{[185.7]}\end{array}$ & $\begin{array}{l}-165.0 \\
{[250.3]}\end{array}$ & $\begin{array}{l}-0.0166 \\
{[0.0691]}\end{array}$ & $\begin{array}{c}0.119 * \\
{[0.0643]}\end{array}$ & $\begin{array}{l}-0.0817 \\
{[0.0528]}\end{array}$ & $\begin{array}{c}-3.275^{* * *} \\
{[1.045]}\end{array}$ \\
\hline No match & $\begin{array}{c}0.00990 \\
{[0.0136]}\end{array}$ & $\begin{array}{c}7.475 \\
{[8.565]}\end{array}$ & $\begin{array}{l}-55.40 \\
{[169.1]}\end{array}$ & $\begin{array}{l}-314.2 \\
{[239.5]}\end{array}$ & $\begin{array}{l}-0.00889 \\
{[0.0628]}\end{array}$ & $\begin{array}{c}0.0623 \\
{[0.0640]}\end{array}$ & $\begin{array}{l}0.00582 \\
{[0.0554]}\end{array}$ & $\begin{array}{c}1.371 \\
{[1.683]}\end{array}$ \\
\hline \multicolumn{9}{|c|}{$P$-values for tests of equality of coeffcients } \\
\hline $3: 1=1: 1$ & 0.186 & 0.165 & 0.028 & 0.017 & 0.189 & 0.430 & 0.183 & 0.985 \\
\hline $3: 1=$ No match & 0.001 & 0.001 & 0.006 & 0.007 & 0.220 & 0.127 & 0.007 & 0.004 \\
\hline $1: 1=$ No match & 0.004 & 0.006 & 0.596 & 0.556 & 0.920 & 0.457 & 0.164 & 0.003 \\
\hline $3: 1=1: 1=$ No match & 0.000 & 0.000 & 0.017 & 0.018 & 0.335 & 0.311 & 0.027 & 0.009 \\
\hline Observations & 387 & 387 & 387 & 387 & 387 & 387 & 387 & 387 \\
\hline R-squared & 0.145 & 0.137 & 0.103 & 0.105 & 0.082 & 0.085 & 0.103 & 0.099 \\
\hline Control group mean & 0 & 0 & 1412 & 2233 & 0.74 & 0.26 & 0.28 & 5.19 \\
\hline \multicolumn{9}{|c|}{ Panel 2: Male target students } \\
\hline 3:1 match & $\begin{array}{l}0.115^{* * *} \\
{[0.0366]}\end{array}$ & $\begin{array}{c}55.96 * * * \\
{[18.83]}\end{array}$ & $\begin{array}{c}43.57 \\
{[186.7]}\end{array}$ & $\begin{array}{c}8.040 \\
{[224.8]}\end{array}$ & $\begin{array}{l}-0.0595 \\
{[0.0681]}\end{array}$ & $\begin{array}{r}0.00546 \\
{[0.0636]}\end{array}$ & $\begin{array}{l}-0.116^{*} \\
{[0.0701]}\end{array}$ & $\begin{array}{c}-5.144 * * * \\
{[1.866]}\end{array}$ \\
\hline $1: 1$ match & $\begin{array}{c}0.00842 \\
{[0.0184]}\end{array}$ & $\begin{array}{c}7.756 \\
{[10.88]}\end{array}$ & $\begin{array}{c}64.92 \\
{[195.1]}\end{array}$ & $\begin{array}{c}284.4 \\
{[276.5]}\end{array}$ & $\begin{array}{c}-0.0536 \\
{[0.0587]}\end{array}$ & $\begin{array}{c}-0.0383 \\
{[0.0644]}\end{array}$ & $\begin{array}{c}-0.0441 \\
{[0.0666]}\end{array}$ & $\begin{array}{c}-2.555 \\
{[2.028]}\end{array}$ \\
\hline No match & $\begin{array}{c}-0.0129 \\
{[0.0143]}\end{array}$ & $\begin{array}{c}-7.167 \\
{[7.916]}\end{array}$ & $\begin{array}{c}-27.38 \\
{[189.5]}\end{array}$ & $\begin{array}{c}2.470 \\
{[234.8]}\end{array}$ & $\begin{array}{c}0.0115 \\
{[0.0709]}\end{array}$ & $\begin{array}{c}0.0897 \\
{[0.0739]}\end{array}$ & $\begin{array}{c}0.0310 \\
{[0.0681]}\end{array}$ & $\begin{array}{c}-1.852 \\
{[2.332]}\end{array}$ \\
\hline \multicolumn{9}{|c|}{$P$-values for tests of equality of coefficients } \\
\hline $3: 1=1: 1$ & 0.023 & 0.047 & 0.921 & 0.370 & 0.934 & 0.526 & 0.373 & 0.176 \\
\hline $3: 1=$ No match & 0.003 & 0.005 & 0.724 & 0.985 & 0.385 & 0.308 & 0.111 & 0.112 \\
\hline $1: 1=$ No match & 0.305 & 0.214 & 0.647 & 0.370 & 0.397 & 0.108 & 0.263 & 0.766 \\
\hline $3: 1=1: 1=$ No match & 0.007 & 0.011 & 0.886 & 0.598 & 0.628 & 0.274 & 0.264 & 0.184 \\
\hline Observations & 341 & 341 & 341 & 341 & 341 & 341 & 341 & 341 \\
\hline R-squared & 0.161 & 0.146 & 0.058 & 0.078 & 0.109 & 0.061 & 0.079 & 0.096 \\
\hline Control group mean & 0 & 0 & 1287 & 2000 & 0.74 & 0.27 & 0.39 & 8.86 \\
\hline
\end{tabular}




\section{ONLINE APPENDIX for}

Channeling Remittances to Education: A Field Experiment Among Migrants from El Salvador

By:

Kate Ambler, International Food Policy Research Institute

Diego Aycinena, Universidad Francisco Marroquin

Dean Yang, University of Michigan, NBER, and BREAD 


\section{$\underline{\text { Online Appendix A: Project Marketing Materials }}$}

\section{Table of Contents:}

General information handout provided to all participants..............................

EduRemesas informational pamphlet provided to all those offered the EduRemesa..........3

No match group coupon provided to no match treatment group........................5

1:1 match group coupon provided to $1: 1$ match treatment group $\ldots \ldots \ldots \ldots \ldots \ldots \ldots \ldots \ldots \ldots$

3:1 match group coupon provided to $3: 1$ match treatment group....................... 


\title{
Promoviendo la Educación en El Salvador
}

\section{Estudio de los Hermanos Lejanos para el Desarrollo de El Salvador}

\author{
(EHLD Salvador)
}

\section{LA SITUACION}

El Salvador está enfrentando un desafío en los niveles educativos superiores. A pesar de que 9 de cada 10 niños en

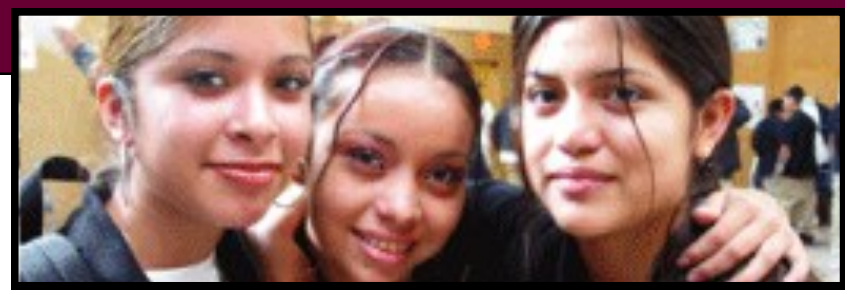
edad escolar están matriculados en el nivel básico, solamente 3 de cada 10 jóvenes llegan a matricularse en bachillerato. Los jóvenes Salvadoreños necesitan apoyo para continuar sus estudios en estos niveles educativos superiores y poder desarrollar las habilidades y obtener los conocimientos que necesitan para salir adelante.

\section{COMO LAS REMESAS PUEDEN AYUDAR}

Sus remesas pueden hacer mucho para mejorar esta situación. Una manera efectiva de apoyar a un estudiante es la siguiente:

Cada año, destine una suma de dinero cuyo propósito es apoyar con la educación de un estudiante especifico en El Salvador. De esta manera usted puede estar seguro que el estudiante tendrá soporte económico para todo el año escolar. Los montos de dinero típicamente destinados están entre $\$ 300-\$ 500$ anuales para estudiantes en el nivel bachillerato, y $\$ 600-\$ 800$ anuales para estudiantes en el nivel técnico superior.

En lugar de enviar el dinero al padre o tutor del estudiante, puede ser más eficaz permitirles a los estudiantes recibir y gastar el dinero que va destinado para su educación. De esta manera, puede estar seguro de que el dinero será utilizado para apoyar su educación y no en otros gastos del hogar. ¡Esto también enseña al estudiante a ser responsable y puede ser fuente de motivación para que les vaya mejor en la escuela! Para mandar el dinero directamente al estudiante, una cuenta bancaria puede ser abierta a nombre del estudiante.

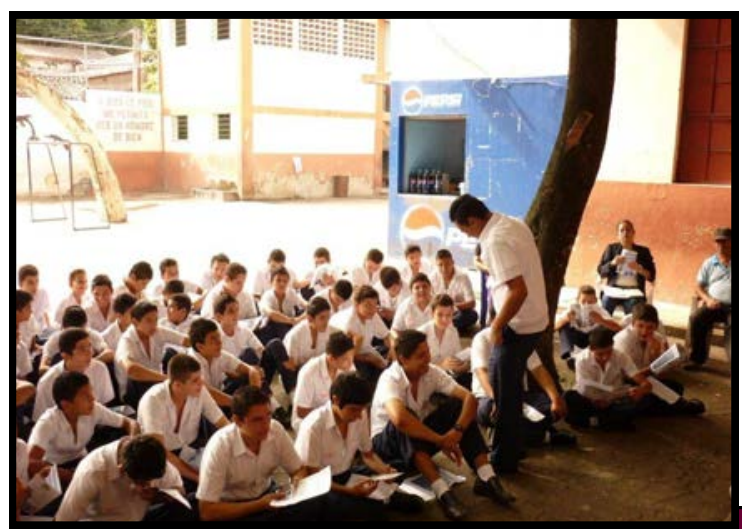

Usted puede enviar el dinero en 10 cantidades iguales durante el transcurso del año escolar con el fin de que el estudiante utilice el dinero responsablemente y no envié todo el dinero a la vez. Otra manera importante como usted puede ayudar a su familiar a que tenga éxito es pedirle que le envíe sus calificaciones al final de cada ciclo académico. iSu supervisión también puede servir como motivación para que el estudiante se esfuerce más y le vaya mejor en sus estudios! 


\section{¿Quienes Somos?}

\section{EduRemesas}

EduRemesas es un iniciativa de:

\section{FEPADE}

La Fundación Empresarial para el Desarrollo Educativo (FEPADE) es una organización salvadoreña sin fines de lucro dedicada al desarrollo integral de la educación y capacitación de los salvadoreños. Desde sus inicios FEPADE se propuso capacitar efectivamente a la mayor cantidad de personas, con el fin de ayudarles a obtener empleos y así mejorar su nivel de vida.
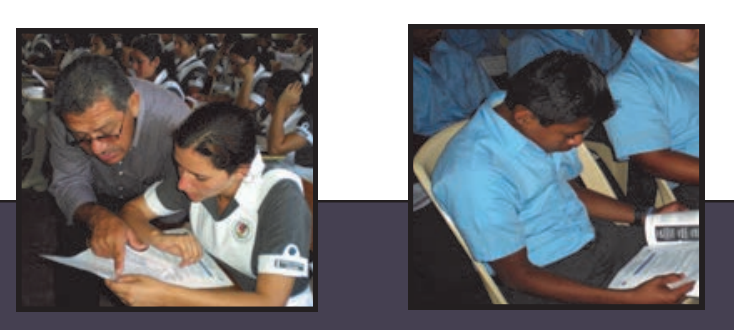

\section{Contáctenos!}

*Por favor incluya su ID único en todas las comunicaciones

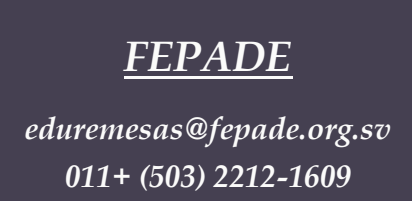

\section{$\underline{\text { IPA }}$}

info@ehld.org +01-202-695-EHLD (+01-202-695-3453)

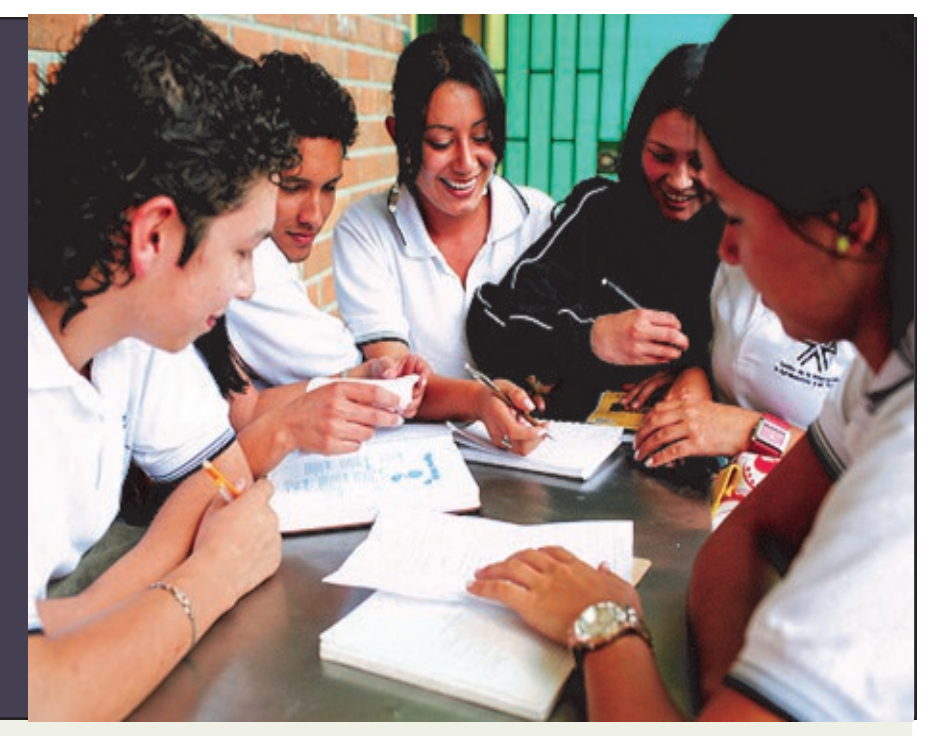

\section{IPA}

Innovaciones para la Acción contra la Pobreza (IPA) es una organización sin fines de lucro. Con experiencia trabajando en más de 40 países, IPA se dedica a desarrollar y promover programas que realmente ayudan al desarrollo de los países. IPA trabaja con una variedad de organizaciones, incluyendo otras organizaciones sin fines de lucro, universidades, gobiernos, y empresas privadas.

\section{Hermanos Lejanos}

Apoyando EL SALVADOR 


\section{EduRemesas}

\section{Detalles y Preguntas Frecuentes}

\section{¿Qué es EduRemesas?}

EduRemesas es un servicio de FEPADE que les permite a los migrantes salvadoreños patrocinar a un estudiante en El Salvador.

¿A quién puedo patrocinar?

El alumno puede ser cualquier persona que usted conozca, siempre y cuando el estudiante se encuentre en el nivel de bachillerato o técnico superior durante del año escolar 2012.

\section{¿Cuáles son las ventajas de EduRemesas?}

- ¡Usted puede dirigir su dinero directamente a un estudiante en vez de mandarlo a otras personas, $\mathrm{CO}^{-}$ mo su tutor $\mathrm{u}$ otro adulto!

- ¡El estudiante tendrá dinero para pagar sus gastos educativos a la vez que aprenderá a manejar sus fondos educativos y a ser responsable!

- ¡Usted hace un solo envío de dinero al inicio del año escolar y el estudiante recibirá una cuota cada meses, durante de los 10 meses que dura el año escolar!

¿De cuánto es EduRemesas?

Normalmente, el 15\% de cada EduRemesa sería utilizado para cubrir los costos administrativos de FEPADE. Sin embargo, por un tiempo limitado y únicamente para participantes del EHLD Salvador, EHLD Salvador subsidiará todos los costos de las EduRemesas. !Esto significa que Usted sólo necesita pagar la tarifa del envío de la remesa a FEPADE!

El monto que usted puede enviar para apoyar al estudiante dependerá del nivel de estudio del estudiante. Hay dos montos para cada nivel de estudio y usted puede elegir enviar uno de los dos:

\section{- Bachillerato}

USD 300 anual (\$30 cada mes por 10 meses)

USD 500 anual ( $\$ 50$ cada mes por 10 meses)

- Técnico superior

USD 600 anual ( $\$ 60$ cada mes por 10 meses)

USD 800 anual (\$80 cada mes por 10 meses)

\section{¿Cómo funciona?}

1. Usted envía a FEPADE una remesa a través de cualquier agente de Viamericas antes del inicio del año escolar 2012. Usted incluirá con esta remesa:

$$
\text { - Su EHLD ID único }
$$

- Nombre, dirección y número de teléfono del estudiante al que quiere patrocinar.

2. Después de recibir esta remesa, FEPADE se comunicara con el estudiante para que el estudiante mande a FEPADE copias de sus documentos de identificación (DUI y NIT si tiene 18 años o más, o carnet de minoridad si es menor de 18).

3. FEPADE encargará de abrir una cuenta bancaria al nombre del estudiante para que puede acceder al dinero que usted le manda y reunirá con el estudiante para entregarle su tarjeta de debito. FEPADE no puede abrir esta cuenta si no tiene copias de sus documentos de identidad.

4. FEPADE depositará el dinero enviado por usted mensualmente en la cuenta bancaria del estudiante en cantidades iguales durante cada uno de los 10 meses del año escolar 2012.

5. ¡Cada mes el estudiante retirará el dinero depositado por FEPADE con su tarjeta de débito y con ella pagará los costos relacionados a su educación!

\section{¿Puedo patrocinar a más de un estudiante?}

Cada estudiante solamente puede beneficiarse de una EduRemesa para el año escolar 2012. Sin embargo, no hay un límite al número de EduRemesas que usted puede mandar.

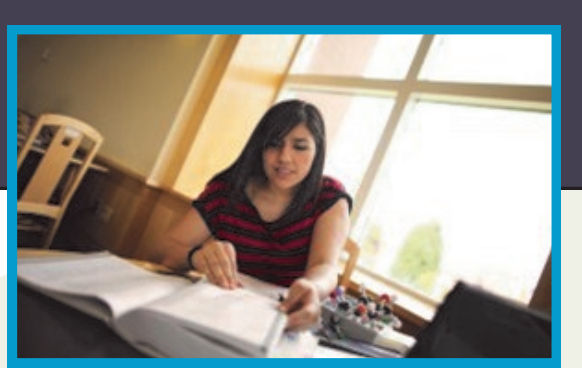

¡Quiero mandar una EduRemesa! ¿Qué hago para registrarme?

Llenar la Aplicación Inicial ahora, inclusive si es que no está seguro de que quiere participar. FEPADE necesitará la información para procesar su aplicación, pero no se le obligará a participar!

Si usted no terminó la aplicación durante de su entrevista inicial, llame a IPA parar poder terminarla. 'También, llame a IPA con cualquier pregunta que tenga!

Hablar con el estudiante y su familia en El Salvador para contarles de esta oportunidad.

Mandar una remesa a FEPADE a través de Viamericas con el monto que usted ha elegido.

*Llame 1-800-401-7626 para encontrar un Viamericas cerca a usted.

Notificarle al estudiante en El Salvador que sera contactado por FEPADE y que deberá de tener los números (y copias) de sus documentos de identificación listos para entregar a FEPADE. Esto incluye copias de:

\section{- Carnet de minoridad para estudiantes} menores de 18 anos

- DUI y NIT para estudiantes de 18 años o más.

¡Listo! ¡FEPADE coordinará la reunión con el estudiante, abrirá una cuenta para el estudiante, y realizará los desembolsos al estudiante! 


\section{TEDUREMESAS PROMOCION ESPECIAL!}

¡NO SE TE COBRARÁ EL 15\% DE LOS GASTOS ADMINISTRATIVOS!

VALIDA SOLAMENTE POR EDUREMESAS PARA EL AÑO ESCOLAR 2012

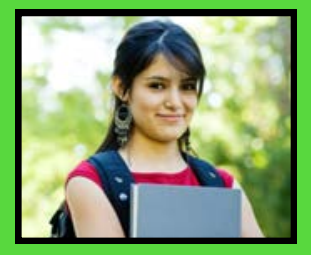

SU EHLD ID:

200109

¡PARA ASEGURAR TU DESCUENTO, INCLUYE TU EHLD ID EN LA REMESA QUE ENVIES POR VIAMERICAS! Este cupón expira 31/3/2012 


\section{PEDUREMESAS PROMOCION ESPECIAL!}

\section{¡NO SE TE COBRARÁ EL 15\% DE LOS GASTOS ADMINISTRATIVOS}

$y$

POR CADA \$ 1 OUE ENVIES A FEPADE, EHLD Salvador ENVIARÁ \$1 ADICIONAL!

VALIDA SOLAMENTE POR EDUREMIESAS PARA EL AÑO ESCOLAR 2012

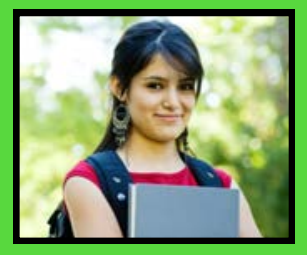

\begin{tabular}{|ccc|}
$\begin{array}{c}\text { Si usted } \\
\text { envia... }\end{array}$ & $\begin{array}{r}\text { EHLD Salvador } \\
\text { enviará.. }\end{array}$ & $\begin{array}{r}\text { y su estudiante recibirá } \\
\text { una EduRemesa de... }\end{array}$ \\
\hline$\$ 150$ & $\$ 150$ & $\mathbf{\$ 3 0 0}$ \\
$\$ 250$ & $\$ 250$ & $\mathbf{\$ 5 0 0}$ \\
$\$ 300$ & $\$ 300$ & $\mathbf{\$ 6 0 0}$ \\
$\$ 400$ & $\$ 400$ & $\mathbf{\$ 8 0 0}$ \\
\hline
\end{tabular}

SU EHLD ID

200108

¡PARA ASEGURAR TU DESCUENTO, INCLUYE TU EHLD ID EN LA REMESA QUE ENVIES POR VIAMERICAS! Este cupón expira 31/3/2012 


\section{PEDUREMESAS PROMOCION ESPECIAL!}

¡NO SE TE COBRARÁ EL 15\% DE LOS GASTOS ADMINISTRATIVOS POR CADA \$1 OUE ENVIES A FEPADE, EHLD Salvador ENVIARÁ \$3 ADICIONALES!

VALIDA SOLAMINTE POR EDUREMIESAS PARA EL AÑO ESCOLAR 2012

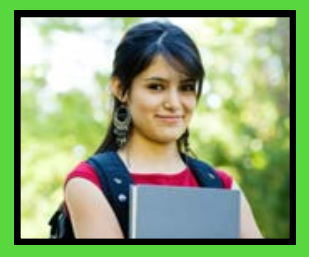

\begin{tabular}{|ccc|}
$\begin{array}{c}\text { Si usted } \\
\text { envia... }\end{array}$ & $\begin{array}{c}\text { EHLD Salvador } \\
\text { enviará.. }\end{array}$ & $\begin{array}{c}\text { y su estudiante recibirá } \\
\text { una EduRemesa de... }\end{array}$ \\
\hline$\$ 75$ & $\$ 225$ & $\mathbf{\$ 3 0 0}$ \\
$\$ 125$ & $\$ 375$ & $\mathbf{\$ 5 0 0}$ \\
$\$ 150$ & $\$ 450$ & $\mathbf{\$ 6 0 0}$ \\
$\$ 200$ & $\$ 600$ & $\mathbf{\$ 8 0 0}$ \\
\hline
\end{tabular}

SU EHLD ID:

200110 


\section{Online Appendix B: Variable definitions}

Data used in this paper came from three surveys. Baseline surveys were conducted with migrants between early November 2011 and early February 2012. Follow-up surveys were conducted by phone with migrants and the target household in El Salvador (both the target student and a responsible adult) from mid July 2012 to late October 2012. A second follow-up was conducted approximately one year after the first in October and November 2013. We also use administrative data from the EduRemesa project. Because El Salvador uses the US dollar as its official currency, all monetary figures are in US dollars. Following are descriptions of all variables used for baseline summary statistics and dependent variables in regressions.

\section{Variables from baseline survey}

Migrant is female is equal to one if migrant is female and zero if migrant is male.

Migrant age is migrant's age in years, calculated from reported date of birth.

Migrant is married is equal to one if migrant reports being married or cohabiting and zero otherwise. It is derived from asking for the migrant's civil status.

Migrant household size in the US is the total number of persons (including the migrant) living in the migrant's home in the United States.

Migrant annual remittances to target household is the total amount sent by the migrant to the target household in the 12 months preceding the survey. This equals the frequency of regular remittance transactions over the past 12 months multiplied by the average amount per regular remittance transaction, plus the total amounts reported to have been sent for special occasions in various categories.

Migrant annual remittances to other households is the total amount sent by the migrant to households that are not the target household in the 12 months preceding the survey. This equals the frequency of regular remittance transactions over the past 12 months multiplied by the average amount per regular remittance transaction for each household, plus the total amounts reported to have been sent for special occasions in various categories.

Target student is female is equal to one if the migrant reports the target student is female and zero if migrant reports the target student is male.

Target student age is the migrant's report of the target student's age.

Target student is migrant's child is equal to one if the migrant reports the target student is his/her child and zero if a different relationship is reported. It is derived from a question that asks the migrant to describe his/her relationship with the target student. 
Target student is migrant's sibling is equal to one if the migrant reports the target student is his/her sibling and zero if a different relationship is reported. It is derived from a question that asks the migrant to describe his/her relationship with the target student.

Target student is migrant's niece/nephew is equal to one if the migrant reports the target student is his/her niece/nephew and zero if a different relationship is reported. It is derived from a question that asks the migrant to describe his/her relationship with the target student.

Target student is migrant's cousin is equal to one if the migrant reports the target student is his/her cousin and zero if a different relationship is reported. It is derived from a question that asks the migrant to describe his/her relationship with the target student.

Target student is in school is equal to one if the migrant reports that the target student currently attends school and zero if the migrant reports that the target student does not currently attend school.

Target student years of education is the target student's total number of years of education reported by the migrant. It is the total number of years completed for those students not currently in school and includes the current year for those still in school. It is derived from questions about current level of schooling and number of years within that level.

\section{Variables from EduRemesa administrative data}

EduRemesa sent is equal to one if the migrant sent at least one EduRemesa to any student and zero otherwise.

Number of EduRemesas sent is the total number of EduRemesas sent by each migrant.

Total amount sent by migrant is the total dollar amount contributed by each migrant to EduRemesas, summing across all EduRemesas sent by each migrant.

Total amount sent by migrant plus subsidy is the total dollar amount contributed by each migrant to EduRemesas plus the project subsidy, summing across all EduRemesas sent by each migrant.

EduRemesa sent to target student is equal to one if the migrant sent an EduRemesa to his/her designated target student and zero otherwise.

Total amount sent by migrant to target student is the total dollar amount contributed by each migrant to EduRemesas for his/her target student.

Total amount sent by migrant plus subsidy to target student is the total dollar amount contributed by each migrant to EduRemesas for his/her target student plus the project subsidy.

\section{Variables from the EI Salvador follow-up survey}


These variable descriptions refer to the main variables from the 2012 follow-up surveys. Parallel variables from the 2013 follow-up data are constructed in the same way, but refer to 2013 instead of 2012.

\section{Target student expenditures on education:}

Spending on all categories is asked with reference to the period since January 1, 2012 (2013 for second follow-up) and then annualized in the manner described below for each category. For all categories both target students and the responsible adult were asked if there were expenditures in each category. If yes, they were asked how much was spent. The student report is given priority and the responsible adult report is used when the student report is missing. If both are missing, the value is imputed to allow for consistent sample size. Imputations were performed by regressing expenditure in each category on student age, gender, whether student is in school, the type of school, education level, and number of people 22 and under in the student's household using the control group. The data comes from the student reports in El Salvador follow-up survey. This regression is then used to predict values for the missing values in each expenditure category.

\section{Target student expenditure on:}

Tuition is the annual amount spent on tuition for the target student. It is sum of two categories: annual tuition paid in a lump sum at the beginning of the school and monthly tuition paid every month. Monthly tuition report is multiplied by ten (for ten month school year) to arrive at annual figure.

Follow-up 2012:

Student report: $99.2 \%$

Adult report: $0.7 \%$

Imputed value: $0.1 \%$

Follow-up 2013:

Student report: $99.6 \%$

Adult report: $0.4 \%$

Imputed value: $0.0 \%$

School supplies is the annual amount on school supplies for the target student.

Follow-up 2012:

Student report: $97.7 \%$

Adult report: $2.2 \%$

Imputed value: $0.1 \%$

Follow-up 2013:

Student report: $99.4 \%$

Adult report: $0.4 \%$ 
Imputed value: $0.2 \%$

Uniforms is the annual amount spent on school uniforms for the target student.

Follow-up 2012:

Student report: $99.2 \%$

Adult report: $0.7 \%$

Imputed value: $0.1 \%$

Follow-up 2013:

Student report: $99.6 \%$

Adult report: $0.2 \%$

Imputed value: $0.2 \%$

Books is the annual amount spent on school books for the target student.

Follow 2012:

Student report: $98.6 \%$

Adult report: $1.0 \%$

Imputed value: $0.4 \%$

Follow-up 2013:

Student report: $99.4 \%$

Adult report: $0.2 \%$

Imputed value: $0.4 \%$

Transport is the annual amount spent on transportation to and from school for the target student. It is reported as a weekly expenditure and multiplied by 43 for a 10 month school year.

Follow-up 2012:

Student report: $99.7 \%$

Adult report: $0.3 \%$

Imputed value: $0.0 \%$

Follow-up 2013:

Student report: $100.0 \%$

Adult report: $0.0 \%$

Imputed value: $0.0 \%$

Food is the annual amount spent by the target student for food purchased while at school. It is reported as a weekly expenditure and multiplied by 43 for a 10 month school year.

Follow-up 2012:

Student report: $99.9 \%$

Adult report: $0.1 \%$

Imputed value: $0.0 \%$ 
Follow-up 2013:

Student report: $99.8 \%$

Adult report: $0.2 \%$

Imputed value: $0.0 \%$

Computer use is the annual amount spent by the target student for computer use related to school work. It is reported as a weekly expenditure and multiplied by 43 for a 10 month school year.

Follow-up 2012:

Student report: $99.4 \%$

Adult report: $0.5 \%$

Imputed value: $0.1 \%$

Follow-up 2013:

Student report: $99.2 \%$

Adult report: $0.2 \%$

Imputed value: $0.6 \%$

Other are expenditures that do not fit into any category. These are reported in the frequency of the respondent's choice and multiplied by the appropriate number to annualize for the 10 month school year.

Follow-up 2012:

Student report: $99.9 \%$

Adult report: $0.1 \%$

Imputed value: $0.0 \%$

Follow-up 2013:

Student report: $100.0 \%$

Adult report: $0.0 \%$

Imputed value: $0.0 \%$

Total target student education expenditures is the sum of all the preceding target student education expenditure variables.

Follow-up 2012:

All categories are student report: $95.4 \%$

At least one adult report: $4.0 \%$

At least one imputed value: $0.8 \%$

Follow-up 2013:

All categories are student report: $98.0 \%$

At least one adult report: $0.9 \%$

At least one imputed value: $1.1 \%$ 
Total household expenditures on education:

Spending on all categories is asked with reference to the period since January 1, 2012 (2013 for second follow-up) and then annualized in the manner described below for each category. For all categories amounts are the target student amount described above plus the amount spent on each additional child in the household in that expenditure category. The additional student reports come from the responsible adult. For each category and for each additional child the responsible adult was asked if there were expenditures in each category. If yes, they are asked how much was spent. If report is missing, the value is imputed to allow for consistent sample size. Imputations were performed by regressing expenditure in each category on additional student age, gender, whether student is in school, the type of school, education level, and number of people 22 and under in the student's household using the control group. The data comes from the adult reports in El Salvador follow-up survey. This regression is then used to predict values for the missing values in each expenditure category.

Total household expenditure on:

Tuition is the annual amount spent on tuition. It is sum of two categories: annual tuition paid in a lump sum at the beginning of the school and monthly tuition paid every month. Monthly tuition report is multiplied by ten (for ten month school year) to arrive at annual figure.

At least one imputed value:

2012: $0.8 \%$

2013: $1.3 \%$

School supplies is the annual amount on school supplies.

At least one imputed value:

2012: $1.1 \%$

2013: $2.8 \%$

Uniforms is the annual amount spent on school uniforms.

At least one imputed value:

2012: $0.3 \%$

2013: $1.5 \%$

Books is the annual amount spent on school books.

At least one imputed value:

2012: $1.9 \%$

2013: $2.2 \%$

Transport is the annual amount spent on transportation to and from school. It is reported as a weekly expenditure and multiplied by 43 for a 10 month school year.

At least one imputed value:

2012: $0.1 \%$

2013: $0.9 \%$ 
Food is the annual amount spent on food purchased while at school. It is reported as a weekly expenditure and multiplied by 43 for a 10 month school year.

At least one imputed value:

2012: $0.2 \%$

2013: $1.5 \%$

Computer use is the annual amount spent on computer use related to school work. It is reported as a weekly expenditure and multiplied by 43 for a 10 month school year.

At least one imputed value:

2012: $0.5 \%$

2013: $2.0 \%$

Other are expenditures that do not fit into any category. These are reported in the frequency of the respondent's choice and multiplied by the appropriate number to annualize for the 10 month school year.

At least one imputed value:

2012: $1.3 \%$

2013: $0.0 \%$

Total household education expenditures is the sum of all the preceding household education expenditure variables.

At least one imputed value:

2012: $4.5 \%$

2013: $5.9 \%$

\section{$\underline{\text { Target student education outcomes: }}$}

Target student is in school is equal to one if the target student reports he/she is currently attending school and zero if he/she reports that he/she is not.

Target student is in any private school is equal to one if the target student reports that he/she attends either parochial school or non-parochial private school. It is equal to zero if target student reports attending public school or the target student is not currently in school.

Target student is in parochial school is equal to one if the target student reports that he/she attends parochial school. It is equal to zero if target student reports attending non-parochial private school, public school, or the target student is not currently in school.

Target student is in other private school is equal to one if the target student reports that he/she attends a non-parochial private school. It is equal to zero if target student reports attending parochial private school, public school, or the target student is not currently in school.

\section{Target student labor force outcomes:}

Paid work is equal to one if the target student reports currently spending time working at a job where he/she receives pay and zero otherwise. 
Average hours per week paid work is the number of weekly hours the target student reports spending on average at the job(s) where he/she receives pay. It is equal to zero for target students who said they did not perform paid work.

Unpaid work is equal to one if the target student reports currently spending time working at a job where he/she does not receive pay and zero otherwise.

Average hours per week unpaid work is the number of weekly hours the target student reports spending on average at the job(s) where he/she does not receive pay. It is equal to zero for target students who said they did not perform unpaid work.

Any work is equal to one if the target student reports doing any work and zero otherwise. It is derived from responses to paid work and unpaid work.

Average hours per week any work is the number of weekly hours the target student reports spending on average at any job. It is the sum of average hours per week paid work and average hours per week unpaid work.

\section{Variables from the migrant follow-up survey}

$\underline{\text { Remittances sent by migrant: }}$

All remittance variables refer to the total amount sent by the migrant since January 1, 2012. For each category (regular and special occasion remittances to the target household and other households) missing values are imputed to ensure consistent sample size. Imputations are done by regressing the amount in each category on migrant age, migrant gender, years the migrant has been in the US, annual regular and special occasion remittances to the target household and other households, migrant years of education, an indicator variable for whether or not the migrant's spouse is in the US, the number of children the migrant has living in the US, and an indicator variable for whether or not the migrant has a child under 23 living in El Salvador using the control group. The data comes from the baseline survey. This regression is then used to predict values for the missing values.

Remittances to target household is the total amount sent by the migrant to the target household since January 1, 2012. This equals the number of regular remittances sent since January 1, 2012 multiplied by the average amount of each remittance, plus the total amounts reported to have been sent for special occasions in various categories since January 1, 2012. This figure does not include any funds that may have been sent as an EduRemesa.

Imputed value: $16.2 \%$

Remittance to other households is the total amount sent by the migrant to households that are not the target household since January 1, 2012. This equals the number of regular remittances sent to other households since January 1, 2012 multiplied by the average amount per regular remittance for each household, plus the total amounts reported to have been sent for special occasions in 
various categories. This figure does not include any funds that may have been sent as an EduRemesa.

Imputed value: $4.6 \%$

Overall total is the sum of remittances to the target household and to other household. Imputed value: $19.6 \%$

Inverse hyperbolic sine transformation of remittance variables is the three above remittance variables transformed as follows: $\log \left(\mathrm{y}_{\mathrm{i}}+\left(\mathrm{y}_{\mathrm{i}}{ }^{2}+1\right)^{1 / 2}\right)$. 


\section{Online Appendix C: Discussion and Additional Analyses}

In this online appendix we provide additional discussion and analyses to clarify the interpretation of results. We also report on results of an additional treatment.

\section{Ruling out marketing effects}

One might be concerned that some other aspect of the 3:1 match treatment is contributing to the observed increase in education expenditures, aside from the EduRemesa funds provided. In particular, participants received encouragement to channel remittances to education as part of the marketing of the EduRemesa, so it is possible that some of the increase in expenditures could be the result of a marketing effect.

Our experiment was designed precisely to eliminate such concerns. While migrants in the control group did not receive the offer of an EduRemesa, they did receive a flyer that suggested ways migrants could enhance remittance impacts on education that highlighted the features of the EduRemesa (specifically, the flyer suggested sending funds directly to the sponsored student and disbursing funds in monthly installments).

In addition, we can compare the results in the 3:1 match group to the no match group where the EduRemesa was also offered but without subsidy. The marketing effect should be the same in both groups, while take up was zero in the no match group, so the difference in outcomes between these groups should only be due to the EduRemesa funds received. Across most of the outcomes where the 3:1 match treatment had a statistically significant effect (target student education expenditures, household education expenditures, and the labor supply outcomes), the 3:1 match effect is also statistically significantly different from the effect of the no match treatment. The exception to this is the impact on private school attendance. We therefore view the results as ruling out the possibility that the 3:1 match effect is partly due to the encouragement to invest in education that was part of the marketing of the EduRemesa. ${ }^{1}$

Relative magnitudes of the 3:1 and 1:1 match treatment effects

We focus most of our attention on the substantial impacts of the 3:1 match, but it is also important to consider these effects next to the effects of the 1:1 match. Take up was highest in the 3:1 match group, but it was also positive in the 1:1 group. For example, take up for target students

\footnotetext{
${ }^{1}$ We also note that the marketing treatments were administered to the migrants, not the family members. If the marketing of the EduRemesa increased migrant interest in promoting education in target student households, we would expect to see increases in remittances sent to these households. But as discussed above, we find no increase in remittances sent by migrants to the target households.
} 
was $6 \%$ in the $1: 1$ group compared to $15 \%$ in the $3: 1$ match group (Table 3, column 5). Given this level of take up and the large effects of the 3:1 treatment, one might have expected to see positive, but smaller, effects of the 1:1 treatment on expenditures and other outcomes. We do find this for some key outcomes: the 1:1 match increases tuition expenditures and reduces labor supply (point estimates are smaller in magnitude than those of the 3:1 match, but not statistically significantly so). However, we do not find statistically significant increases in total target student expenditures due to the 1:1 match (although the coefficient on total expenditures for the 1:1 match treatment in column 1 of Table 5 is positive.) Looking across outcome variables, the broad pattern of these findings is that the 1:1 match also has positive effects but that are smaller in magnitude and less often statistically significant compared to the effects of the 3:1 match.

\section{EduRemesa with and without monitoring of beneficiary student grades}

During the first stage randomization migrants offered the EduRemesa were randomized into being offered one of two versions of the product: half of migrants were randomly assigned to be offered a version of the EduRemesa where they would receive official reports of their beneficiary students' grades at the end of every grading period ("EduRemesa with grades"), and the remaining migrants were offered the EduRemesa without this grade reporting ("EduRemesa without grades").

We included this randomization to test whether the impact of the EduRemesa offer could be enhanced by providing the migrant improved monitoring of student performance. We hypothesized that migrants offered the EduRemesa with grades might take up the product at higher rates. In addition, conditional on taking up, the EduRemesa with grades could have provided greater incentive for households to spend more on education.

Online Appendix Table 11 analyzes take up separately for the EduRemesa with grades and the EduRemesa without grades. Take up in the 3:1 match group does not vary by whether or not the migrant was offered grade reports, and this is true across all measures of take up. The similarity in treatment effects for the EduRemesa with and without grades is also evident in the analysis of target student educational expenditures (Online Appendix Table 12). The only evidence of differences across the EduRemesa with and without grades is in take up in the 1:1 match group, which is higher for the EduRemesa without grades. It is not obvious why the EduRemesa without grades would have led to higher take up, but we speculate that migrants may have not wanted to bear the effort cost of monitoring students in El Salvador that would be expected with the 
EduRemesa with grades treatment. We do not place great emphasis on this result, however, since the corresponding pattern (higher take up for the EduRemesa without grades) does not hold for the 3:1 match treatment. Overall, we conclude from this analysis that migrants do not appear to place value on monitoring the performance of students funded via the EduRemesa. 


\section{Online Appendix D: Longer-Term Impacts}

In this section we present the results of the second follow-up survey intended to study the longer-term impacts of the EduRemesa program. Because the EduRemesa transfers were offered only for the 2012 school year, this longer-term follow-up, conducted at the end of the 2013 school year, examines impacts on behavior after the EduRemesa transfers have ended. The second followup was almost identical in content to the first, and was also conducted over the phone, but was limited to the target student and a knowledgeable adult. Because the second follow-up survey instrument was similar to the first, we are able to replicate the same analyses, using the same econometric specifications. A larger degree of attrition resulted in a smaller estimation sample for the second follow-up (459 target students), but in Online Appendix Table 13, we show that attrition is not related to treatment for the combined student-adult sample or either sample separately. The combined sample will be used for all analyses in this section. Table structure is as in the main analysis.

Online Appendix Table 14 reports the effect of the EduRemesa treatments on annualized target student education expenditure for 2013. Although the coefficients are imprecise, the pattern and magnitude of the results are similar to the results in Table 5 for expenditures in 2012, suggesting that the EduRemesa may have led families to maintain this higher level of expenditures even after the transfer ended. However, only two coefficients are statistically significantly different from zero at the 10\% level (food expenditures for the 3:1 match and tuition expenditures for the 1:1 match) so very little should be interpreted from these results. It should also be noted that while the impact of the 3:1 match treatment on total target student expenditures is larger in magnitude for females than for males, this difference is much more subtle than in the results in Table 5, and again, neither coefficient is statistically significant.

The impacts of the EduRemesa treatments on household education expenditures in 2013 are presented in Online Appendix Table 15. Again, the same very rough pattern of results from Table 6 is present, but the standard errors are even larger here than in the estimates presented in Online Appendix Table 14, and the coefficients are not stable across treatments and subsamples. Overall, the results on educational expenditures, both at the target student and household level, are somewhat suggestive of continued impacts, but due to lack of power no definitive conclusions can or should be drawn from the results. Given the lack of a first stage in these analyses, we do not 
repeat the instrumental variables regressions from Table 7 with the data from the second followup.

Online Appendix Table 16 shows the estimates for the impact of the EduRemesa treatments on target student education outcomes in the second follow-up sample. Again, the coefficients are imprecise due to our small sample, but, as in the first follow-up, there is no evidence that the EduRemesa treatments affect whether or not a target student is in school (column 1). In contrast to the first follow-up, here the point estimate for whether or not a target student is in private school (column 2) is close to zero in the pooled sample. That point estimate is however larger in magnitude and positive in the female sub-sample only, which is more consistent with the results from the first follow-up round. This would suggest that some of the female target students who switched to private school because of the EduRemesa were able to stay in private school for the 2013 school year. However, again, none of these coefficients are statistically significant and the confidence intervals are large enough to encompass a wide range of possible outcomes.

As a final analysis using the second follow-up, we analyze the impact of the EduRemesa treatments on student labor force participation in 2013. The results are shown in Online Appendix Table 17. Here, as in the other analyses, there are not statistically significant results for labor force participation either on the extensive or the intensive margin. In contrast to the large impacts found for both male and female target students in 2012 (Table 9), not only are the coefficients for 2013 imprecise, but they are also much smaller in magnitude than in 2012, suggesting that the labor supply effects did not, in fact, persist into 2013. 


\section{Online Appendix E: Appendix Tables and Figures}

Appendix Figure 1: Treatment groups

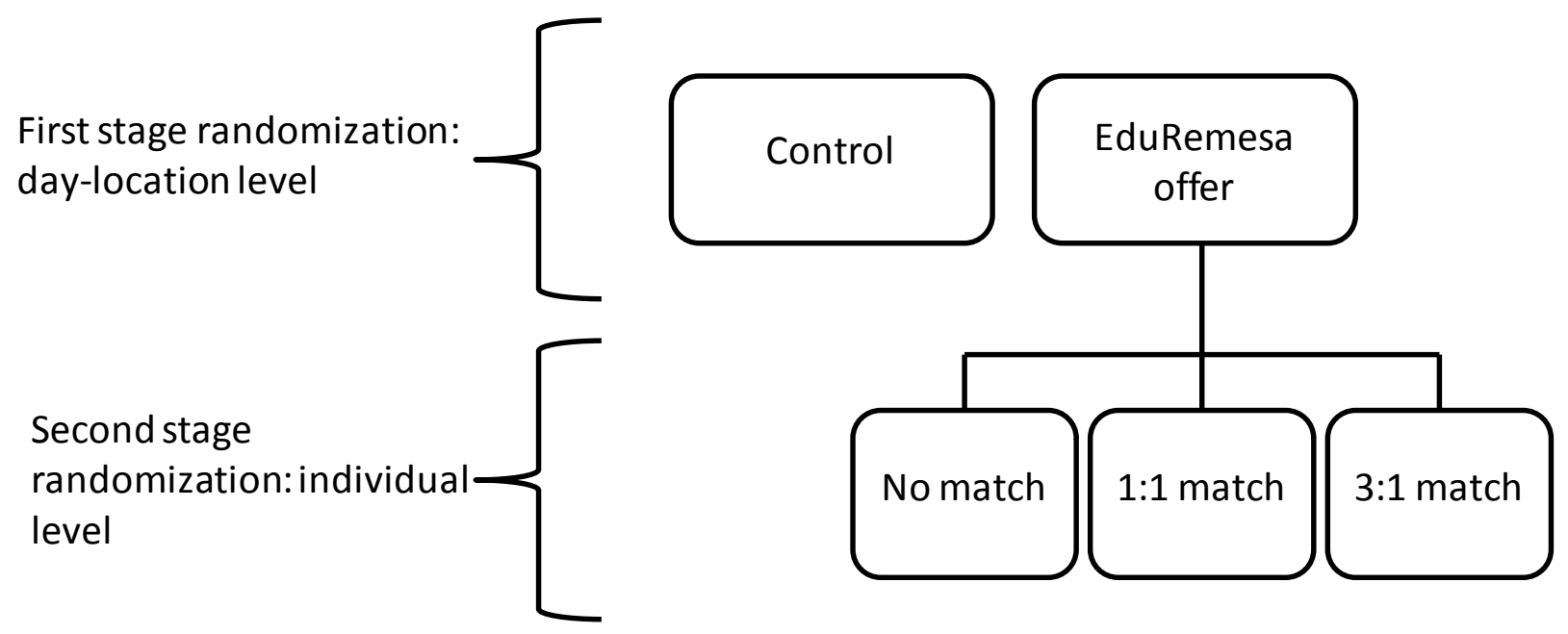




\section{Appendix Figure 2: Cumulative distribution functions of total target student education}

expenditure

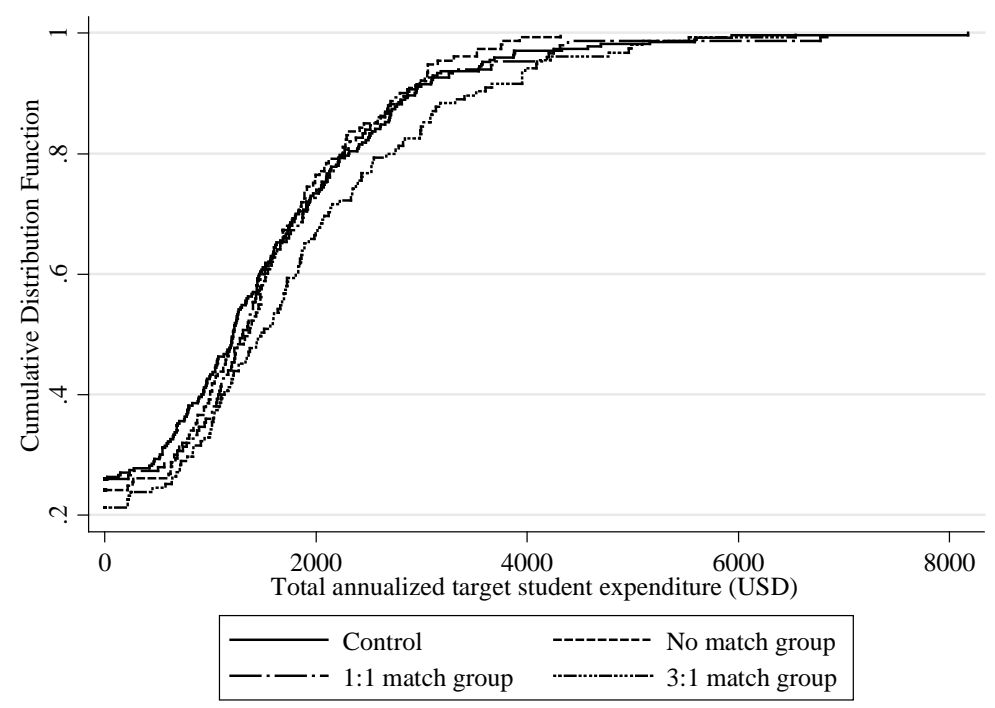

Notes: Sample is all migrant-student pairs with completed El Salvador follow-up surveys. Expenditures in US dollars.

\section{Appendix Figure 3: Cumulative distribution functions of total target student hours worked}

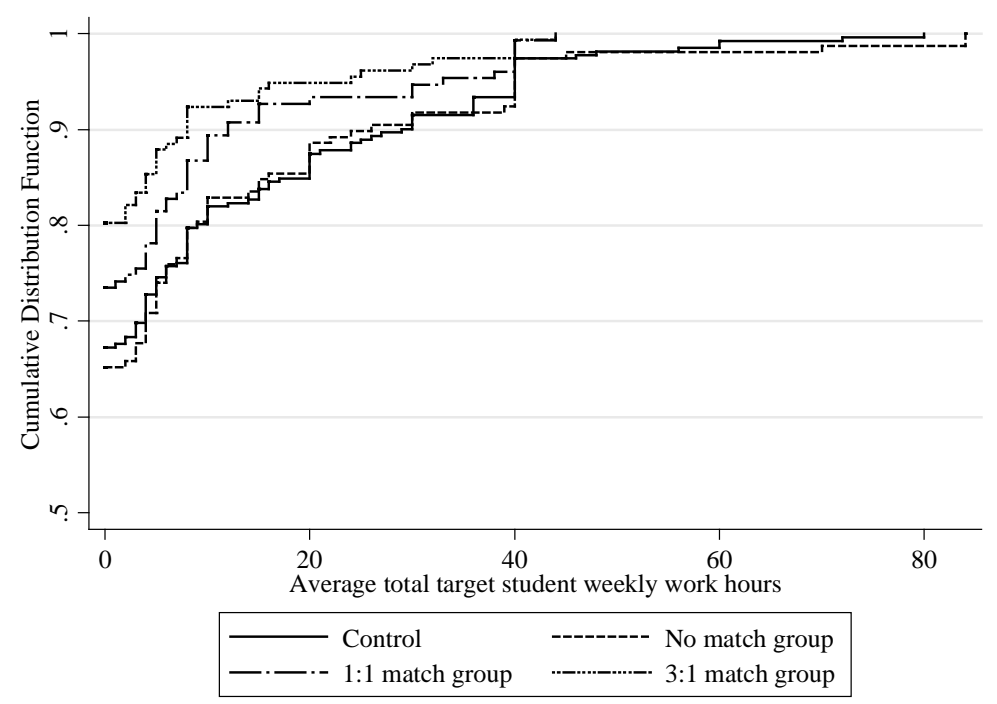

Notes: Sample is all migrant-student pairs with completed El Salvador follow-up surveys. 
Appendix Table 1: Type of school by school level, current students, El Salvador

\begin{tabular}{lccc}
\hline \hline & Primary & Secondary & Tertiary \\
\hline Public & & & \\
& $89.06 \%$ & $78.90 \%$ & $38.92 \%$ \\
Private & & & \\
$\quad$ Parochial & $4.94 \%$ & $21.10 \%$ & $61.08 \%$ \\
Other private & $6.60 \%$ & $5.31 \%$ & $5.76 \%$ \\
\hline \hline
\end{tabular}

Notes: Source is El Salvador Encuesta de Hogares de Propositos Multiples 2010. 
Appendix Table 2: EduRemesa amounts and migrant contributions by treatment group

\begin{tabular}{cccccc}
\hline \hline & & \multicolumn{4}{c}{ Treatment groups } \\
& & & No match & $\mathbf{1 : 1}$ match & 3:1 match \\
\cline { 3 - 5 } EduRemesa & Secondary & $\mathbf{\$ 3 0 0}$ & $\$ 300$ & $\$ 150$ & $\$ 75$ \\
amounts & & $\mathbf{\$ 5 0 0}$ & $\$ 500$ & $\$ 250$ & $\$ 125$ \\
(USD) & \multirow{2}{*}{ Tertiary } & $\mathbf{\$ 6 0 0}$ & $\$ 600$ & $\$ 300$ & $\$ 150$ \\
& & $\mathbf{\$ 8 0 0}$ & $\$ 800$ & $\$ 400$ & $\$ 200$ \\
\cline { 3 - 5 } & & & & & \\
\hline \hline
\end{tabular}


Appendix Table 3A: Baseline summary statistics

\begin{tabular}{|c|c|c|c|c|c|c|c|c|}
\hline Variable & Mean & Std. Dev. & Min & 10th pct. & Median & 90th pct. & Max & $\mathbf{N}$ \\
\hline Migrant is female & 0.50 & 0.50 & 0 & 0 & 0 & 1 & 1 & 728 \\
\hline Migrant age & 36.88 & 9.43 & 15 & 26 & 36 & 49 & 74 & 709 \\
\hline Migrant is married & 0.60 & 0.49 & 0 & 0 & 1 & 1 & 1 & 724 \\
\hline Migrant years of education & 9.12 & 4.66 & 0 & 1 & 9 & 14 & 21 & 717 \\
\hline Migrant years in US & 11.22 & 6.37 & 0 & 5 & 10 & 21 & 38 & 726 \\
\hline Migrant annual remittance to target hh (USD) & 2,684 & 3,463 & 0 & 0 & 1,750 & 7,050 & 31,620 & 713 \\
\hline Target student is female & 0.53 & 0.50 & 0 & 0 & 1 & 1 & 1 & 728 \\
\hline Target student age & 18.50 & 3.20 & 11 & 15 & 18 & 23 & 38 & 713 \\
\hline \multicolumn{9}{|l|}{ Target student is migrant's... } \\
\hline ...child & 0.26 & 0.44 & 0 & 0 & 0 & 1 & 1 & 727 \\
\hline ...sibling & 0.25 & 0.43 & 0 & 0 & 0 & 1 & 1 & 727 \\
\hline ...niece/nephew & 0.33 & 0.47 & 0 & 0 & 0 & 1 & 1 & 727 \\
\hline
\end{tabular}

Notes: Sample is all migrant-student pairs with completed El Salvador follow-up surveys. Variables all come from migrant baseline survey. Sample size varies slighly with missing values for each variable. All money amounts are in US dollars. 
Appendix Table 3B: Baseline summary statistics: Full sample

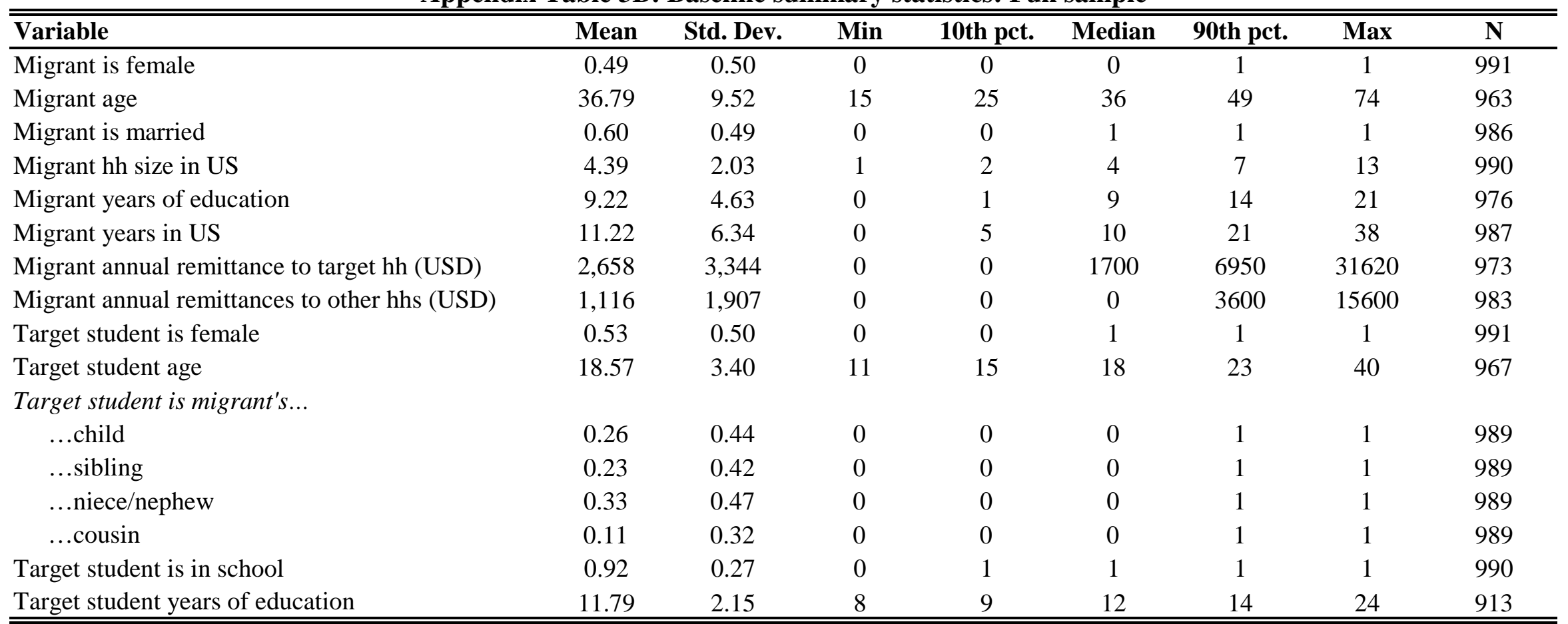

Notes: Sample is all migrant-student pairs interviewed at baseline. Variables all come from migrant baseline survey. Sample size varies slighly with missing values for each variable. All money amounts are in US dollars. 
Appendix Table 3C: Baseline summary statistics: Migrant follow-up sample

\begin{tabular}{|c|c|c|c|c|c|c|c|c|}
\hline Variable & Mean & Std. Dev. & Min & 10th pct. & Median & 90th pct. & Max & $\mathbf{N}$ \\
\hline Migrant is female & 0.50 & 0.50 & 0 & 0 & 0 & 1 & 1 & 735 \\
\hline Migrant age & 37.28 & 9.56 & 17 & 26 & 36 & 50 & 74 & 717 \\
\hline Migrant is married & 0.62 & 0.49 & 0 & 0 & 1 & 1 & 1 & 733 \\
\hline Migrant years of education & 9.07 & 4.69 & 0 & 0 & 9 & 14 & 21 & 724 \\
\hline Migrant years in US & 11.08 & 6.34 & 0 & 5 & 10 & 21 & 38 & 733 \\
\hline Migrant annual remittance to target hh (USD) & 2,765 & 3,413 & 0 & 0 & 1,800 & 7,200 & 31,620 & 724 \\
\hline Target student is female & 0.55 & 0.50 & 0 & 0 & 1 & 1 & 1 & 735 \\
\hline Target student age & 18.51 & 3.40 & 11 & 15 & 18 & 23 & 40 & 724 \\
\hline \multicolumn{9}{|l|}{ Target student is migrant's... } \\
\hline ...child & 0.28 & 0.45 & 0 & 0 & 0 & 1 & 1 & 735 \\
\hline ...sibling & 0.23 & 0.42 & 0 & 0 & 0 & 1 & 1 & 735 \\
\hline ...niece/nephew & 0.33 & 0.47 & 0 & 0 & 0 & 1 & 1 & 735 \\
\hline
\end{tabular}

Notes: Sample is all migrant-student pairs with completed migrant follow-up surveys. Variables all come from migrant baseline survey. Sample size varies slighly with missing values for each variable. All money amounts are in US dollars. 


\section{Appendix Table 4: Comparison of migrants in study with DC-area Salvadorans in the American Community Survey}

\begin{tabular}{lcc}
\hline \hline & & $\begin{array}{c}\text { American Community } \\
\text { Survey: 2008-2010 3- } \\
\text { year sample }\end{array}$ \\
& $\begin{array}{c}\text { El Salvador follow-up } \\
\text { sample }\end{array}$ & $\begin{array}{c}\text { Salvadoran-born, not US } \\
\text { citizen }\end{array}$ \\
\hline & & \\
Migrant is female & 0.50 & 0.46 \\
Age of migrant & 35.91 & 36.05 \\
& {$[11.01]$} & {$[10.39]$} \\
Migrant's years in the US & 11.19 & 12.93 \\
& {$[6.38]$} & {$[7.89]$} \\
Migrant's hh size in the US & 4.48 & 4.95 \\
Migrant has less than high school education & {$[2.09]$} & {$[2.12]$} \\
Migrant has high school education or more & 0.61 & 0.61 \\
& 0.39 & 0.39 \\
Observations & & 2,208 \\
\hline \hline
\end{tabular}

Notes: Baseline survey sample is all migrant-student pairs with completed El Salvador follow-up surveys. Because of missing values, sample size for baseline survey education variables is 723. ACS sample is the IPUMS three year 2008-2010 ACS sample restricted to individuals 18-65 in the Washington, DC metro area (as defined by the ACS, includes MD and VA suburbs). Standard deviation in brackets for continuous variables. 
Appendix Table 5A: Baseline balance: Full sample

\begin{tabular}{|c|c|c|c|c|c|c|c|c|c|}
\hline & \multirow[b]{2}{*}{ Control } & \multicolumn{3}{|c|}{ Means } & \multicolumn{4}{|c|}{ P-values } & \multirow[b]{2}{*}{$N$} \\
\hline & & No match & 1:1 match & 3:1 match & $\begin{array}{c}C=N M= \\
1: 1=3: 1\end{array}$ & $\mathrm{C}=\mathrm{NM}$ & $C=1: 1$ & $C=3: 1$ & \\
\hline Migrant is female & 0.47 & 0.48 & 0.51 & 0.54 & 0.233 & 0.651 & 0.273 & 0.052 & 991 \\
\hline Migrant age & 36.63 & 36.42 & 36.67 & 37.53 & 0.665 & 0.789 & 0.678 & 0.298 & 963 \\
\hline Migrant is married & 0.58 & 0.59 & 0.65 & 0.61 & 0.535 & 0.849 & 0.208 & 0.552 & 986 \\
\hline Migrant hh size in US & 4.48 & 4.47 & 4.37 & 4.18 & 0.466 & 0.810 & 0.469 & 0.246 & 990 \\
\hline Migrant years of education & 9.32 & 9.11 & 9.21 & 9.16 & 0.970 & 0.714 & 0.886 & 0.648 & 976 \\
\hline Migrant years in US & 10.87 & 11.13 & 10.97 & 12.15 & 0.147 & 0.575 & 0.804 & 0.028 & 987 \\
\hline Migrant annual remittance to target hh (USD) & 2,838 & 2,419 & 2,520 & 2,717 & 0.372 & 0.150 & 0.263 & 0.763 & 973 \\
\hline Migrant annual remittances to other hhs (USD) & 1,223 & 1,021 & 996 & 1,147 & 0.635 & 0.320 & 0.269 & 0.748 & 983 \\
\hline Target student is female & 0.56 & 0.56 & 0.50 & 0.46 & 0.038 & 0.830 & 0.142 & 0.033 & 991 \\
\hline Target student age & 18.48 & 18.65 & 18.65 & 18.55 & 0.693 & 0.313 & 0.352 & 0.409 & 967 \\
\hline \multicolumn{10}{|l|}{ Target student is migrant's... } \\
\hline ...child & 0.25 & 0.23 & 0.27 & 0.29 & 0.481 & 0.295 & 0.842 & 0.611 & 989 \\
\hline ...sibling & 0.23 & 0.28 & 0.21 & 0.23 & 0.227 & 0.072 & 0.608 & 0.630 & 989 \\
\hline ...niece/nephew & 0.32 & 0.33 & 0.37 & 0.32 & 0.520 & 0.548 & 0.150 & 0.760 & 989 \\
\hline ...cousin & 0.12 & 0.13 & 0.10 & 0.09 & 0.446 & 0.543 & 0.579 & 0.334 & 989 \\
\hline Target student is in school & 0.91 & 0.90 & 0.93 & 0.94 & 0.434 & 0.280 & 0.680 & 0.472 & 990 \\
\hline Target student years of education & 11.80 & 11.47 & 11.98 & 11.92 & 0.101 & 0.181 & 0.210 & 0.244 & 913 \\
\hline
\end{tabular}

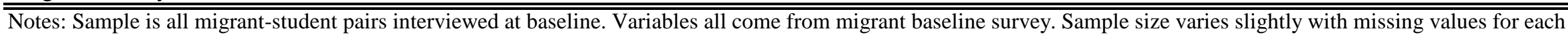
variable. P-values come from regressions of each baseline variable on the treatment variables, including stratification cell fixed effects for week and location of baseline survey, with standard errors clustered at the level of the day and location of the baseline survey. All money amounts are in US dollars. 
Appendix Table 5B: Baseline balance: Migrant follow-up sample

\begin{tabular}{|c|c|c|c|c|c|c|c|c|c|}
\hline & \multirow[b]{2}{*}{ Control } & \multicolumn{3}{|c|}{ Means } & \multicolumn{4}{|c|}{$P$-values } & \multirow[b]{2}{*}{$N$} \\
\hline & & No match & $1: 1$ match & $3: 1$ match & $\begin{array}{c}\mathrm{C}=\mathrm{NM}= \\
1: 1=3: 1\end{array}$ & $C=N M$ & $C=1: 1$ & $C=3: 1$ & \\
\hline Migrant is female & 0.49 & 0.47 & 0.51 & 0.52 & 0.662 & 0.781 & 0.475 & 0.306 & 735 \\
\hline Migrant age & 37.14 & 37.16 & 36.98 & 37.87 & 0.966 & 0.793 & 0.831 & 0.788 & 717 \\
\hline Migrant is married & 0.61 & 0.60 & 0.64 & 0.62 & 0.937 & 0.633 & 0.765 & 0.981 & 733 \\
\hline Migrant hh size in US & 4.58 & 4.67 & 4.45 & 4.34 & 0.358 & 0.332 & 0.533 & 0.404 & 735 \\
\hline Migrant years of education & 9.06 & 9.17 & 9.04 & 9.01 & 0.989 & 0.813 & 0.996 & 0.889 & 724 \\
\hline Migrant years in US & 10.75 & 11.33 & 11.12 & 11.34 & 0.807 & 0.383 & 0.640 & 0.483 & 733 \\
\hline Migrant annual remittance to target hh (USD) & 3,005 & 2,445 & 2,670 & 2,743 & 0.438 & 0.108 & 0.343 & 0.587 & 724 \\
\hline Migrant annual remittances to other hhs (USD) & 1,321 & 1,007 & 1,035 & 1,275 & 0.489 & 0.205 & 0.212 & 0.910 & 730 \\
\hline Target student is female & 0.57 & 0.58 & 0.54 & 0.48 & 0.107 & 0.934 & 0.336 & 0.031 & 735 \\
\hline Target student age & 18.44 & 18.57 & 18.52 & 18.57 & 0.869 & 0.448 & 0.585 & 0.557 & 724 \\
\hline \multicolumn{10}{|l|}{ Target student is migrant's... } \\
\hline ...child & 0.27 & 0.25 & 0.30 & 0.33 & 0.411 & 0.324 & 0.573 & 0.404 & 735 \\
\hline ...sibling & 0.23 & 0.26 & 0.20 & 0.21 & 0.512 & 0.385 & 0.344 & 0.617 & 735 \\
\hline ...niece/nephew & 0.32 & 0.34 & 0.37 & 0.31 & 0.572 & 0.514 & 0.210 & 0.950 & 735 \\
\hline ...cousin & 0.09 & 0.12 & 0.07 & 0.09 & 0.501 & 0.164 & 0.762 & 0.799 & 735 \\
\hline Target student is in school & 0.91 & 0.88 & 0.94 & 0.94 & 0.247 & 0.371 & 0.196 & 0.218 & 735 \\
\hline Target student years of education & 11.77 & 11.39 & 11.92 & 11.85 & 0.224 & 0.194 & 0.377 & 0.582 & 683 \\
\hline
\end{tabular}

Notes: Sample is all migrant-student pairs for completed migrant follow-up surveys. Variables all come from migrant baseline survey. Sample size varies slightly with missing values for each variable. P-values come from regressions of each baseline variable on the treatment variables, including stratification cell fixed effects for week and location of baseline survey, with standard errors clustered at the level of the day and location of the baseline survey. All money amounts are in US dollars. 
Appendix Table 6: Attrition

(1) (2)

(3)

El Salvador follow- Migrant follow-up Both follow-ups up complete complete complete

\begin{tabular}{lccc}
\hline & & & \\
$3: 1$ match & -0.0345 & 0.0178 & -0.000549 \\
& {$[0.0355]$} & {$[0.0365]$} & {$[0.0426]$} \\
$1: 1$ match & -0.0240 & -0.0459 & -0.0577 \\
& {$[0.0363]$} & {$[0.0368]$} & {$[0.0422]$} \\
No match & -0.0266 & -0.00370 & -0.0464 \\
& {$[0.0374]$} & {$[0.0390]$} & {$[0.0468]$} \\
& & & \\
$P$-values for tests of equality of coefficients & & \\
3:1=1:1 & 0.803 & 0.089 & 0.184 \\
$3: 1=$ No match & 0.871 & 0.634 & 0.376 \\
$1: 1=$ No match & 0.952 & 0.302 & 0.816 \\
$3: 1=1: 1=$ No match & 0.969 & 0.209 & 0.397 \\
& & & \\
Observations & 991 & 991 & 991 \\
R-squared & 0.030 & 0.040 & 0.022 \\
Control group mean & 0.75 & 0.76 & 0.61 \\
\hline \hline
\end{tabular}

Notes: Robust standard errors clustered at the level of the day and location of the baseline survey in brackets. There are 126 dayXlocation clusters in each regression. Sample is all migrant-student pairs interviewed at baseline. All regressions include stratification cell fixed effects for the week and location of the baseline survey.

*** $\mathrm{p}<0.01, * * \mathrm{p}<0.05, * \mathrm{p}<0.1$ 
Appendix Table 7: Number of EduRemesas sent by amount and treatment group

\begin{tabular}{|c|c|c|c|c|c|c|}
\hline \multirow{7}{*}{$\begin{array}{r}\text { EduRemesa } \\
\text { amounts }\end{array}$} & & \multicolumn{4}{|c|}{ Treatment groups } & \multirow[b]{2}{*}{ Total } \\
\hline & \multirow{3}{*}{ Secondary } & & No match & 1:1 match & 3:1 match & \\
\hline & & $\$ 300$ & 0 & 1 & 5 & 6 \\
\hline & & $\$ 500$ & 0 & 6 & 22 & 28 \\
\hline & Tertiary & $\$ 600$ & 0 & 2 & 3 & 5 \\
\hline & & $\$ 800$ & 0 & 3 & 10 & 13 \\
\hline & & Total & 0 & 12 & 40 & 52 \\
\hline
\end{tabular}

Notes: Data comes from EduRemesas administrative data. Sample is all migrant-student pairs interviewed at baseline. 
(1)

(2)

(3)
(5)

(6)

(7)

Total amount

Total amount

EduRemesa

sent
EduRemesa sent to target student
Total amount sent by migrant to

target student

\section{sent by}

migrant plus

matching

funds sent by

migrant to

target student plus matching funds

\begin{tabular}{|c|c|c|c|c|c|c|c|}
\hline \multirow[t]{2}{*}{ 3:1 match } & $0.145^{* * *}$ & $0.188 * * *$ & $26.24 * * *$ & $105.0 * * *$ & $0.120 * * *$ & $16.92^{* * *}$ & $67.25 * * *$ \\
\hline & [0.0245] & [0.0354] & [4.997] & [19.47] & [0.0216] & [3.131] & [11.96] \\
\hline \multirow[t]{2}{*}{ 1:1 match } & $0.0520 * * *$ & $0.0633 * * *$ & $17.03^{* * *}$ & $36.20 * * *$ & $0.0443 * * *$ & $13.55^{* * *}$ & $26.93 * * *$ \\
\hline & [0.0153] & [0.0194] & {$[5.446]$} & [11.62] & [0.0144] & [4.508] & [9.207] \\
\hline \multirow[t]{2}{*}{ No match } & -0.000802 & 0.00213 & 0.242 & 1.838 & -0.00235 & -0.130 & -0.380 \\
\hline & [0.00735] & [0.00988] & [1.853] & [5.245] & [0.00704] & [1.414] & [3.701] \\
\hline
\end{tabular}

$P$-values for tests of equality of coefficients

\begin{tabular}{|c|c|c|c|c|c|c|c|}
\hline \\
\hline $3: 1=1: 1$ & 0.001 & 0.002 & 0.232 & 0.004 & 0.005 & 0.541 & 0.010 \\
\hline 3:1 = No match & 0.000 & 0.000 & 0.000 & 0.000 & 0.000 & 0.000 & 0.000 \\
\hline $1: 1=$ No match & 0.001 & 0.004 & 0.004 & 0.005 & 0.003 & 0.003 & 0.004 \\
\hline $3: 1=1: 1=$ No match & 0.000 & 0.000 & 0.000 & 0.000 & 0.000 & 0.000 & 0.000 \\
\hline Observations & 991 & 991 & 991 & 991 & 991 & 991 & 991 \\
\hline R-squared & 0.103 & 0.089 & 0.063 & 0.080 & 0.091 & 0.059 & 0.078 \\
\hline Control group mean & 0 & 0 & 0 & 0 & 0 & 0 & 0 \\
\hline
\end{tabular}

Notes: Robust standard errors clustered at the level of the day and location of the baseline survey in brackets. There are 126 dayXlocation clusters in each regression. Sample is all migrant-student pairs interviewed at baseline. All regressions include stratification cell fixed effects for the week and location of the baseline survey. Dependent variables are from EduRemesa administrative data. All money amounts are in US dollars.

$* * * \mathrm{p}<0.01, * * \mathrm{p}<0.05, * \mathrm{p}<0.1$ 
Appendix Table 8B: Takeup of EduRemesa by treatment: Migrant follow-up sample

(1)

EduRemesa
sent

(2)

(3)
(4)

(5)

Total amount

$\begin{array}{cc}\text { Number of } & \text { Total amount } \\ \text { EduRemesas } & \text { sent by } \\ \text { sent } & \text { migrant }\end{array}$

sent by

migrant plus

matching

funds
(6)

(7)

Total amount sent by

EduRemesa sent to target student

Total amount migrant to sent by migrant to target student target student plus matching funds

\begin{tabular}{|c|c|c|c|c|c|c|c|}
\hline 3:1 match & $\begin{array}{l}0.163^{* * *} \\
{[0.0302]}\end{array}$ & $\begin{array}{l}0.221^{* * *} \\
{[0.0453]}\end{array}$ & $\begin{array}{c}30.41 * * * \\
{[6.643]}\end{array}$ & $\begin{array}{c}122.1^{* * *} \\
{[25.95]}\end{array}$ & $\begin{array}{l}0.137 * * * \\
{[0.0267]}\end{array}$ & $\begin{array}{c}19.08 * * * \\
{[3.912]}\end{array}$ & $\begin{array}{c}76.12^{* * *} \\
{[14.85]}\end{array}$ \\
\hline 1:1 match & $\begin{array}{c}0.0718^{* * *} \\
{[0.0215]}\end{array}$ & $\begin{array}{c}0.0923^{* * *} \\
{[0.0278]}\end{array}$ & $\begin{array}{c}25.09 * * * \\
{[7.838]}\end{array}$ & $\begin{array}{c}54.58 * * * \\
{[16.90]}\end{array}$ & $\begin{array}{c}0.0611^{* * *} \\
{[0.0202]}\end{array}$ & $\begin{array}{c}19.25^{* * *} \\
{[6.371]}\end{array}$ & $\begin{array}{c}37.97 * * * \\
{[13.12]}\end{array}$ \\
\hline No match & $\begin{array}{c}-0.00184 \\
{[0.00997]}\end{array}$ & $\begin{array}{c}0.00417 \\
{[0.0137]}\end{array}$ & $\begin{array}{c}1.157 \\
{[2.572]}\end{array}$ & $\begin{array}{c}4.503 \\
{[7.475]}\end{array}$ & $\begin{array}{c}-0.00414 \\
{[0.00990]}\end{array}$ & $\begin{array}{c}0.104 \\
{[1.931]}\end{array}$ & $\begin{array}{c}-0.359 \\
{[5.275]}\end{array}$ \\
\hline \multicolumn{8}{|c|}{$P$-values for tests of equality of coefficients } \\
\hline $3: 1=1: 1$ & 0.010 & 0.012 & 0.596 & 0.021 & 0.025 & 0.981 & 0.055 \\
\hline 3:1 = No match & 0.000 & 0.000 & 0.000 & 0.000 & 0.000 & 0.000 & 0.000 \\
\hline $1: 1=$ No match & 0.001 & 0.003 & 0.003 & 0.003 & 0.003 & 0.002 & 0.003 \\
\hline 3:1 = 1:1 = No match & 0.000 & 0.000 & 0.000 & 0.000 & 0.000 & 0.000 & 0.000 \\
\hline Observations & 735 & 735 & 735 & 735 & 735 & 735 & 735 \\
\hline R-squared & 0.123 & 0.107 & 0.079 & 0.095 & 0.111 & 0.077 & 0.096 \\
\hline Control group mean & 0 & 0 & 0 & 0 & 0 & 0 & 0 \\
\hline
\end{tabular}
each regression. Sample is all migrant-student pairs with completed migrant follow-up surveys. All regressions include stratification cell fixed effects for the week and location of the baseline survey. Dependent variables are from EduRemesa administrative data. All money amounts are in US dollars.

*** $\mathrm{p}<0.01, * * \mathrm{p}<0.05, * \mathrm{p}<0.1$ 


\begin{tabular}{|c|c|c|c|}
\hline & (1) & (2) & (3) \\
\hline & $\begin{array}{l}\text { El Salvador foll } \\
\text { up complete }\end{array}$ & $\begin{array}{l}\text { srant follow-up } \\
\text { complete }\end{array}$ & $\begin{array}{l}\text { Both follow-ups } \\
\text { complete }\end{array}$ \\
\hline \multicolumn{4}{|c|}{ Panel 1: Female target students } \\
\hline 3:1 match & $\begin{array}{l}-0.0160 \\
{[0.0512]}\end{array}$ & $\begin{array}{c}0.0221 \\
{[0.0490]}\end{array}$ & $\begin{array}{l}0.00986 \\
{[0.0583]}\end{array}$ \\
\hline 1:1 match & $\begin{array}{l}-0.0412 \\
{[0.0535]}\end{array}$ & $\begin{array}{l}-0.0145 \\
{[0.0523]}\end{array}$ & $\begin{array}{l}-0.0425 \\
{[0.0630]}\end{array}$ \\
\hline No match & $\begin{array}{c}-0.0649 \\
{[0.0491]}\end{array}$ & $\begin{array}{c}-0.0297 \\
{[0.0490]}\end{array}$ & $\begin{array}{c}-0.0882 \\
{[0.0555]}\end{array}$ \\
\hline \multicolumn{4}{|c|}{$P$-values for tests of equality of coeffcients } \\
\hline $3: 1=1: 1$ & 0.673 & 0.533 & 0.454 \\
\hline 3:1 = No match & 0.436 & 0.341 & 0.125 \\
\hline $1: 1=$ No match & 0.692 & 0.807 & 0.522 \\
\hline $3: 1=1: 1=$ No match & 0.737 & 0.611 & 0.306 \\
\hline Observations & 522 & 522 & 522 \\
\hline R-squared & 0.052 & 0.073 & 0.049 \\
\hline Control group mean & 0.76 & 0.77 & 0.62 \\
\hline \multicolumn{4}{|c|}{ Panel 2: Male target students } \\
\hline 3:1 match & $\begin{array}{c}-0.0651 \\
{[0.0513]}\end{array}$ & $\begin{array}{c}0.0155 \\
{[0.0445]}\end{array}$ & $\begin{array}{c}-0.0143 \\
{[0.0582]}\end{array}$ \\
\hline 1:1 match & $\begin{array}{c}-0.0133 \\
{[0.0462]}\end{array}$ & $\begin{array}{l}-0.0881^{*} \\
{[0.0516]}\end{array}$ & $\begin{array}{l}-0.0877 \\
{[0.0535]}\end{array}$ \\
\hline No match & $\begin{array}{c}0.00733 \\
{[0.0566]}\end{array}$ & $\begin{array}{c}-0.00127 \\
{[0.0595]}\end{array}$ & $\begin{array}{c}-0.0245 \\
{[0.0688]}\end{array}$ \\
\hline \multicolumn{4}{|c|}{$P$-values for tests of equality of coefficients } \\
\hline $3: 1=1: 1$ & 0.370 & 0.063 & 0.187 \\
\hline 3:1 = No match & 0.308 & 0.797 & 0.894 \\
\hline $1: 1=$ No match & 0.732 & 0.217 & 0.312 \\
\hline $3: 1=1: 1=$ No match & 0.554 & 0.164 & 0.301 \\
\hline Observations & 469 & 469 & 469 \\
\hline R-squared & 0.060 & 0.066 & 0.043 \\
\hline Control group mean & 0.74 & 0.74 & 0.60 \\
\hline
\end{tabular}

Notes: Robust standard errors clustered at the level of the day and location of the baseline survey in brackets. There are 124 dayXlocation clusters in each regression in panel 1 and 119 dayXlocation clusters in each regression in panel 2. Sample is all migrant-student pairs interviewed at baseline. All regressions include stratification cell fixed effects for the week ${ }^{* * *} \mathrm{p}<0.01,{ }^{* *} \mathrm{p}<0.05,{ }^{*} \mathrm{p}<0.1$ 
Appendix Table 10: Baseline balance by gender of target student: El Salvador follow-up sample

\begin{tabular}{|c|c|c|c|c|c|c|c|c|c|}
\hline & \multirow[b]{2}{*}{ Control } & \multicolumn{3}{|c|}{ Means } & \multicolumn{4}{|c|}{ P-values } & \multirow[b]{2}{*}{$N$} \\
\hline & & No match & 1:1 match & 3:1 match & $\begin{array}{c}\mathrm{C}=\mathrm{NM}= \\
1: 1=3: 1\end{array}$ & $\mathrm{C}=\mathrm{NM}$ & $C=1: 1$ & $C=3: 1$ & \\
\hline \multicolumn{10}{|c|}{ Panel 1: Migrant-student pairs with female target student } \\
\hline Migrant is female & 0.48 & 0.46 & 0.52 & 0.52 & 0.683 & 0.622 & 0.371 & 0.320 & 387 \\
\hline Migrant age & 36.88 & 37.21 & 37.42 & 36.18 & 0.619 & 0.534 & 0.542 & 0.638 & 375 \\
\hline Migrant is married & 0.61 & 0.55 & 0.68 & 0.61 & 0.479 & 0.205 & 0.588 & 0.836 & 385 \\
\hline Migrant hh size in US & 4.63 & 4.54 & 4.71 & 4.41 & 0.693 & 0.821 & 0.691 & 0.236 & 387 \\
\hline Migrant years of education & 9.29 & 8.99 & 8.91 & 10.21 & 0.287 & 0.542 & 0.450 & 0.197 & 384 \\
\hline Migrant years in US & 11.24 & 11.74 & 11.19 & 12.15 & 0.794 & 0.383 & 0.960 & 0.677 & 386 \\
\hline Migrant annual remittance to target hh (USD) & 3,046 & 2,243 & 2,580 & 2,955 & 0.458 & 0.126 & 0.506 & 0.865 & 380 \\
\hline Migrant annual remittances to other hhs (USD) & 1,110 & 1,114 & 1,193 & 1,315 & 0.757 & 0.781 & 0.503 & 0.368 & 385 \\
\hline Target student age & 18.42 & 18.21 & 18.58 & 19.35 & 0.091 & 0.755 & 0.535 & 0.036 & 380 \\
\hline \multicolumn{10}{|l|}{ Target student is migrant's... } \\
\hline ...child & 0.25 & 0.18 & 0.35 & 0.25 & 0.070 & 0.108 & 0.213 & 0.913 & 387 \\
\hline ...sibling & 0.25 & 0.30 & 0.21 & 0.31 & 0.464 & 0.254 & 0.847 & 0.257 & 387 \\
\hline ...niece/nephew & 0.35 & 0.40 & 0.33 & 0.28 & 0.368 & 0.257 & 0.862 & 0.278 & 387 \\
\hline ...cousin & 0.08 & 0.08 & 0.08 & 0.09 & 0.982 & 0.934 & 0.724 & 0.995 & 387 \\
\hline Target student is in school & 0.93 & 0.90 & 0.91 & 0.93 & 0.906 & 0.569 & 0.523 & 0.770 & 387 \\
\hline Target student years of education & 11.79 & 11.63 & 11.88 & 12.37 & 0.112 & 0.514 & 0.827 & 0.065 & 357 \\
\hline \multicolumn{10}{|c|}{ Panel 2: Migrant-student pairs with male target student } \\
\hline Migrant is female & 0.44 & 0.52 & 0.55 & 0.54 & 0.391 & 0.457 & 0.138 & 0.219 & 341 \\
\hline Migrant age & 36.60 & 36.40 & 36.22 & 38.06 & 0.705 & 0.895 & 0.554 & 0.452 & 334 \\
\hline Migrant is married & 0.58 & 0.54 & 0.68 & 0.58 & 0.495 & 0.519 & 0.240 & 0.725 & 339 \\
\hline Migrant hh size in US & 4.45 & 4.45 & 4.11 & 4.38 & 0.609 & 0.759 & 0.313 & 0.959 & 341 \\
\hline Migrant years of education & 8.93 & 8.53 & 8.57 & 9.40 & 0.938 & 0.740 & 0.974 & 0.715 & 333 \\
\hline Migrant years in US & 10.44 & 10.63 & 11.00 & 11.64 & 0.319 & 0.847 & 0.380 & 0.092 & 340 \\
\hline Migrant annual remittance to target hh (USD) & 2,856 & 3,003 & 2,235 & 2,187 & 0.223 & 0.813 & 0.150 & 0.200 & 333 \\
\hline Migrant annual remittances to other hhs (USD) & 1,434 & 980 & 867 & 1,368 & 0.310 & 0.197 & 0.121 & 0.830 & 336 \\
\hline Target student age & 18.22 & 18.71 & 18.79 & 18.05 & 0.106 & 0.047 & 0.098 & 0.806 & 333 \\
\hline \multicolumn{10}{|l|}{ Target student is migrant's... } \\
\hline ...child & 0.28 & 0.28 & 0.19 & 0.26 & 0.193 & 0.774 & 0.032 & 0.534 & 340 \\
\hline ...sibling & 0.21 & 0.32 & 0.23 & 0.20 & 0.443 & 0.123 & 0.706 & 0.851 & 340 \\
\hline ...niece/nephew & 0.25 & 0.23 & 0.45 & 0.38 & 0.006 & 0.746 & 0.002 & 0.078 & 340 \\
\hline ...cousin & 0.16 & 0.16 & 0.08 & 0.09 & 0.175 & 0.556 & 0.233 & 0.209 & 340 \\
\hline Target student is in school & 0.91 & 0.90 & 0.96 & 0.95 & 0.174 & 0.284 & 0.303 & 0.413 & 341 \\
\hline Target student years of education & 11.80 & 11.34 & 12.19 & 11.48 & 0.167 & 0.326 & 0.139 & 0.471 & 321 \\
\hline
\end{tabular}

Notes: Sample is all migrant-student pairs with completed El Salvador follow-up surveys. Variables all come from migrant baseline survey. Sample size varies slightly with missing values for each variable. P-values come from regressions of each baseline variable on the treatment variables, including stratification cell fixed effects for week and location of baseline survey, with standard errors clustered at the level of the day and location of the baseline survey. All money amounts are in US dollars. 
Total amount

$\begin{array}{cc}\text { EduRemesa } & \text { Number of } \\ \text { sent } & \text { EduRemesas } \\ \text { sent }\end{array}$

$\begin{array}{cc}\text { Total amount } \\ \text { Total amount } & \text { sent by migrant }\end{array}$ sent sent by migrant plus matching

\section{EduRemesa sent to target} student
Total amount sent by migrant sent by migrant

to target

to target student plus student matching

funds

\begin{tabular}{|c|c|c|c|c|c|c|c|}
\hline 3:1 match \& no grades & $\begin{array}{l}0.180^{* * *} \\
{[0.0444]}\end{array}$ & $\begin{array}{l}0.227 * * * \\
{[0.0670]}\end{array}$ & $\begin{array}{c}31.43^{* * * *} \\
{[8.802]}\end{array}$ & $\begin{array}{c}123.9 * * * \\
{[34.59]}\end{array}$ & $\begin{array}{l}0.138^{* * *} \\
{[0.0395]}\end{array}$ & $\begin{array}{c}20.83^{* * *} \\
{[5.768]}\end{array}$ & $\begin{array}{c}81.59 * * * \\
{[22.38]}\end{array}$ \\
\hline 1:1 match \& no grades & $\begin{array}{l}0.126 * * * \\
{[0.0315]}\end{array}$ & $\begin{array}{c}0.157 * * * \\
{[0.0414]}\end{array}$ & $\begin{array}{c}44.33 * * * \\
{[12.06]}\end{array}$ & $\begin{array}{c}95.28 * * * \\
{[24.82]}\end{array}$ & $\begin{array}{c}0.111^{* * *} \\
{[0.0309]}\end{array}$ & $\begin{array}{c}35.10^{* * *} \\
{[10.00]}\end{array}$ & $\begin{array}{c}71.39 * * * \\
{[20.10]}\end{array}$ \\
\hline No match \& no grades & $\begin{array}{c}0.00794 \\
{[0.0123]}\end{array}$ & $\begin{array}{c}0.0139 \\
{[0.0171]}\end{array}$ & $\begin{array}{c}2.842 \\
{[3.045]}\end{array}$ & $\begin{array}{c}9.908 \\
{[9.146]}\end{array}$ & $\begin{array}{c}0.00655 \\
{[0.0116]}\end{array}$ & $\begin{array}{c}1.903 \\
{[2.197]}\end{array}$ & $\begin{array}{c}5.431 \\
{[6.058]}\end{array}$ \\
\hline 3:1 match \& grades & $\begin{array}{l}0.190 * * * \\
{[0.0480]}\end{array}$ & $\begin{array}{c}0.269 * * * \\
{[0.0670]}\end{array}$ & $\begin{array}{c}38.55^{* * *} \\
{[9.677]}\end{array}$ & $\begin{array}{c}155.1^{* * *} \\
{[39.13]}\end{array}$ & $\begin{array}{c}0.164 * * * \\
{[0.0415]}\end{array}$ & $\begin{array}{c}22.27 * * * \\
{[5.631]}\end{array}$ & $\begin{array}{c}89.16^{* * *} \\
{[22.64]}\end{array}$ \\
\hline 1:1 match \& grades & $\begin{array}{c}0.0100 \\
{[0.0140]}\end{array}$ & $\begin{array}{c}0.0101 \\
{[0.0163]}\end{array}$ & $\begin{array}{c}1.620 \\
{[2.797]}\end{array}$ & $\begin{array}{c}3.453 \\
{[7.709]}\end{array}$ & $\begin{array}{c}0.00887 \\
{[0.0132]}\end{array}$ & $\begin{array}{c}1.576 \\
{[2.489]}\end{array}$ & $\begin{array}{c}2.366 \\
{[5.786]}\end{array}$ \\
\hline No match \& grades & $\begin{array}{c}-0.0109 \\
{[0.0115]}\end{array}$ & $\begin{array}{l}-0.00508 \\
{[0.0146]}\end{array}$ & $\begin{array}{l}-1.044 \\
{[2.659]}\end{array}$ & $\begin{array}{l}-1.771 \\
{[8.051]}\end{array}$ & $\begin{array}{l}-0.00902 \\
{[0.0106]}\end{array}$ & $\begin{array}{l}-1.356 \\
{[2.053]}\end{array}$ & $\begin{array}{c}-3.986 \\
{[5.686]}\end{array}$ \\
\hline \multicolumn{8}{|c|}{$P$-values for tests of equality of coefficients in no grades and grades treatment: } \\
\hline 3:1 match group & 0.876 & 0.658 & 0.570 & 0.537 & 0.650 & 0.853 & 0.810 \\
\hline 1:1 match group & 0.001 & 0.001 & 0.001 & 0.000 & 0.002 & 0.001 & 0.001 \\
\hline No match group & 0.163 & 0.313 & 0.193 & 0.231 & 0.207 & 0.114 & 0.133 \\
\hline Observations & 728 & 728 & 728 & 728 & 728 & 728 & 728 \\
\hline R-squared & 0.147 & 0.125 & 0.107 & 0.115 & 0.128 & 0.106 & 0.114 \\
\hline Control group mean & 0 & 0 & 0 & 0 & 0 & 0 & 0 \\
\hline
\end{tabular}


Appendix Table 12: Target student education expenditures: Interactions with grades treatment

\begin{tabular}{|c|c|c|c|c|c|c|c|c|c|}
\hline & (1) & (2) & (3) & (4) & (5) & (6) & (7) & (8) & (9) \\
\hline & & & pendent $v$ & able: Annuc & zed target & dent expenc & re (USD) & & \\
\hline & Total & Tuition & $\begin{array}{l}\text { School } \\
\text { supplies }\end{array}$ & Uniforms & Books & Transport & Food & $\begin{array}{c}\text { Computer } \\
\text { use }\end{array}$ & Other \\
\hline 3:1 match \& no grades & $347.2^{* *}$ & $129.4 * * *$ & -7.346 & $14.14^{*}$ & 3.387 & $103.7^{*}$ & $122.9 *$ & 23.76 & -42.78 \\
\hline & {$[171.1]$} & {$[44.70]$} & [9.334] & [7.494] & [9.713] & [53.17] & [71.78] & [38.25] & [35.56] \\
\hline 1:1 match \& no grades & 2.681 & $97.33^{* *}$ & -10.08 & -5.372 & 0.968 & 23.44 & 0.241 & -32.89 & $-70.96 * *$ \\
\hline & [131.6] & {$[45.66]$} & [9.030] & {$[5.021]$} & [8.664] & [34.50] & {$[50.70]$} & [30.07] & [33.48] \\
\hline No match \& no grades & 7.252 & 44.10 & 5.482 & -6.593 & $-15.02 * *$ & 26.30 & 31.60 & -23.15 & $-55.47^{*}$ \\
\hline & [144.5] & [45.52] & [10.37] & [6.037] & {$[7.232]$} & [39.73] & [61.11] & [34.91] & [33.37] \\
\hline 3:1 match \& grades & 256.7 & $81.95^{*}$ & 0.714 & -0.154 & 11.19 & 50.39 & $164.3^{* *}$ & -23.43 & -28.25 \\
\hline & [155.5] & [42.05] & [10.62] & [8.128] & [11.17] & [46.87] & {$[77.21]$} & [31.67] & [28.12] \\
\hline 1:1 match \& grades & 147.6 & $68.14^{*}$ & -12.26 & $-12.14^{*}$ & 9.203 & 48.56 & 97.82 & -27.09 & -24.64 \\
\hline & [162.5] & [40.78] & [9.292] & [6.711] & [11.81] & [68.43] & [81.49] & [33.22] & [45.31] \\
\hline No match \& grades & 32.07 & $89.51^{*}$ & -8.145 & -9.059 & -6.785 & -27.84 & 43.28 & -17.80 & -31.09 \\
\hline & [135.4] & [49.21] & [9.239] & [5.762] & [7.916] & [38.37] & [57.01] & [29.97] & [30.16] \\
\hline$P$-values for tests of equ & ity of coeff & ents in no $g$ & les and $g r$ & s treatment & & & & & \\
\hline 3:1 match group & 0.666 & 0.413 & 0.519 & 0.153 & 0.579 & 0.418 & 0.665 & 0.308 & 0.613 \\
\hline 1:1 match group & 0.427 & 0.606 & 0.852 & 0.332 & 0.539 & 0.717 & 0.273 & 0.881 & 0.260 \\
\hline No match group & 0.884 & 0.485 & 0.283 & 0.719 & 0.392 & 0.255 & 0.869 & 0.897 & 0.392 \\
\hline Observations & 728 & 728 & 728 & 728 & 728 & 728 & 728 & 728 & 728 \\
\hline R-squared & 0.034 & 0.054 & 0.033 & 0.056 & 0.034 & 0.044 & 0.047 & 0.039 & 0.052 \\
\hline Control group mean & 1358 & 186.8 & 60.16 & 35.94 & 54.68 & 270.4 & 442.9 & 217.5 & 89.63 \\
\hline
\end{tabular}


Appendix Table 13: Attrition in 2nd follow-up (2013)

\begin{tabular}{lccc}
\hline \hline & $\begin{array}{c}(1) \\
\text { Adult + student } \\
\text { 2nd follow-up } \\
\text { complete }\end{array}$ & $\begin{array}{c}\text { Adult 2nd follow- } \\
\text { up complete }\end{array}$ & $\begin{array}{c}\text { Student 2nd } \\
\text { followup complete }\end{array}$ \\
\hline 3:1 match & -0.0216 & -0.0311 & -0.00845 \\
& {$[0.0394]$} & {$[0.0366]$} & {$[0.0396]$} \\
1:1 match & -0.0126 & -0.0148 & -0.00123 \\
& {$[0.0389]$} & {$[0.0375]$} & {$[0.0390]$} \\
No match & -0.0635 & -0.0604 & -0.0448 \\
& {$[0.0437]$} & {$[0.0421]$} & {$[0.0422]$} \\
& & & \\
$P$-values for tests of equality of coefficients & & 0.871 \\
3:1 = 1:1 & 0.838 & 0.709 & 0.439 \\
3:1 = No match & 0.398 & 0.540 & 0.360 \\
1:1 = No match & 0.299 & 0.355 & 0.625 \\
3:1 = 1:1 = No match & 0.560 & 0.649 & 991 \\
& & & 0.024 \\
Observations & 991 & 991 & 0.503 \\
R-squared & 0.024 & 0.023 & 0.536 \\
Control group mean & 0.486 & & \\
\hline \hline
\end{tabular}

Notes: Robust standard errors clusterd at the level of the day and location of the baseline survey in brackets. There are 126 dayXlocation clusters in each regression. Sample is all migrant-student pairs interviewed at baseline. All regressions include stratification cell fixed effects for the week and location of the baseline survey.

*** $\mathrm{p}<0.01, * * \mathrm{p}<0.05, * \mathrm{p}<0.1$ 
Appendix Table 14: Target student education expenditures in 2nd follow-up (2013)

\begin{tabular}{|c|c|c|c|c|c|c|c|c|c|}
\hline \multirow[t]{3}{*}{ 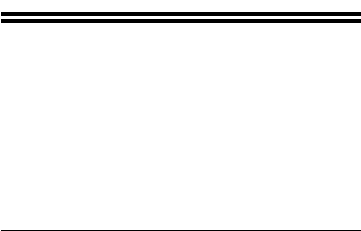 } & $(1)$ & (2) & (3) & (4) & (5) & (6) & $(7)$ & (8) & (9) \\
\hline & \multicolumn{9}{|c|}{ Dependent variable: Annualized target student expenditure (USD) on } \\
\hline & Total & Tuition & $\begin{array}{c}\text { School } \\
\text { supplies }\end{array}$ & Uniforms & Books & Transport & Food & $\begin{array}{c}\text { Computer } \\
\text { use }\end{array}$ & Other \\
\hline \multirow[t]{2}{*}{ 3:1 match } & 246.7 & 23.53 & 0.645 & -0.985 & 1.066 & 51.62 & $109.2 *$ & 10.89 & 50.68 \\
\hline & [187.9] & {$[57.20]$} & {$[14.26]$} & {$[5.577]$} & {$[11.10]$} & {$[62.08]$} & [60.89] & [43.69] & [51.86] \\
\hline \multirow[t]{2}{*}{ 1:1 match } & 106.7 & $119.9 *$ & -15.34 & -8.852 & -1.546 & 25.23 & 70.82 & -51.38 & -32.18 \\
\hline & [190.3] & {$[60.76]$} & {$[12.00]$} & {$[5.955]$} & {$[10.70]$} & {$[61.18]$} & {$[61.21]$} & {$[42.41]$} & [29.60] \\
\hline \multirow[t]{2}{*}{ No match } & 140.2 & 24.64 & -6.825 & 0.475 & -6.745 & 72.80 & 39.93 & 52.48 & -36.59 \\
\hline & {$[180.7]$} & {$[57.66]$} & {$[13.98]$} & {$[6.132]$} & {$[9.551]$} & {$[67.60]$} & [59.63] & {$[57.02]$} & [25.92] \\
\hline \multicolumn{10}{|c|}{$P$-values for tests of equality of coefficients } \\
\hline $3: 1=1: 1$ & 0.530 & 0.179 & 0.175 & 0.254 & 0.838 & 0.689 & 0.619 & 0.223 & 0.133 \\
\hline $3: 1=$ No match & 0.620 & 0.986 & 0.494 & 0.790 & 0.478 & 0.798 & 0.368 & 0.477 & 0.064 \\
\hline $1: 1=$ No match & 0.884 & 0.179 & 0.407 & 0.208 & 0.635 & 0.524 & 0.691 & 0.133 & 0.819 \\
\hline $3: 1=1: 1=$ No match & 0.798 & 0.320 & 0.393 & 0.424 & 0.751 & 0.797 & 0.665 & 0.291 & 0.139 \\
\hline Observations & 459 & 459 & 459 & 459 & 459 & 459 & 459 & 459 & 459 \\
\hline R-squared & 0.081 & 0.098 & 0.048 & 0.075 & 0.056 & 0.045 & 0.064 & 0.083 & 0.123 \\
\hline Control group mean & 1283 & 243.0 & 50.68 & 28.54 & 46.76 & 302.5 & 352.8 & 215.0 & 43.74 \\
\hline
\end{tabular}

Notes: Robust standard errors clusterd at the level of the day and location of the baseline survey in brackets. There are 106 dayXlocation clusters in each regression. Sample is all migrant-student pairs with completed 2nd round follow-up surveys. All regressions include stratification cell fixed effects for the week and location of the baseline survey. All money amounts are in US dollars.

*** $\mathrm{p}<0.01,{ }^{* *} \mathrm{p}<0.05$, * $\mathrm{p}<0.1$ 
Appendix Table 15: Total household education expenditures in 2nd follow-up (2013)

\begin{tabular}{|c|c|c|c|c|c|c|c|c|c|}
\hline \multirow[t]{3}{*}{ 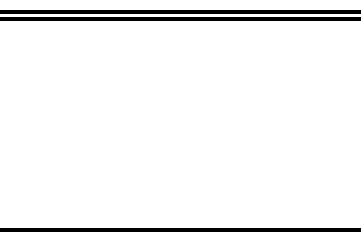 } & $(1)$ & (2) & $(3)$ & $(4)$ & (5) & (6) & $(7)$ & (8) & (9) \\
\hline & \multicolumn{9}{|c|}{ Dependent variable: Annualized target student expenditure (USD) on } \\
\hline & Total & Tuition & $\begin{array}{c}\text { School } \\
\text { supplies }\end{array}$ & Uniforms & Books & Transport & Food & $\begin{array}{c}\text { Computer } \\
\text { use }\end{array}$ & Other \\
\hline \multirow[t]{2}{*}{ 3:1 match } & 148.4 & 49.56 & -1.651 & 1.248 & 4.390 & 46.21 & 150.9 & -54.14 & -48.04 \\
\hline & {$[262.7]$} & {$[85.46]$} & {$[16.44]$} & {$[8.258]$} & {$[13.43]$} & {$[85.61]$} & [97.99] & [63.59] & [34.63] \\
\hline \multirow[t]{2}{*}{ 1:1 match } & 441.0 & $176.4^{*}$ & -10.08 & -15.29 & 4.628 & 170.8 & $226.9 *$ & -48.02 & $-64.36^{* *}$ \\
\hline & [350.3] & [91.48] & {$[14.72]$} & [9.544] & {$[13.70]$} & [123.3] & {$[130.2]$} & [71.77] & [29.33] \\
\hline \multirow[t]{2}{*}{ No match } & 161.3 & 44.89 & 4.299 & 3.937 & -2.870 & 93.10 & 102.5 & -4.224 & $-80.27 * * *$ \\
\hline & [316.9] & [82.84] & [18.09] & [10.66] & [14.19] & [96.66] & [134.7] & [79.42] & [28.66] \\
\hline \multicolumn{10}{|c|}{$P$-values for tests of equality of coefficients } \\
\hline $3: 1=1: 1$ & 0.402 & 0.233 & 0.604 & 0.117 & 0.988 & 0.299 & 0.569 & 0.923 & 0.566 \\
\hline $3: 1=$ No match & 0.966 & 0.956 & 0.751 & 0.799 & 0.605 & 0.673 & 0.735 & 0.487 & 0.291 \\
\hline $1: 1=$ No match & 0.505 & 0.180 & 0.396 & 0.125 & 0.628 & 0.585 & 0.473 & 0.618 & 0.491 \\
\hline $3: 1=1: 1=$ No match & 0.699 & 0.374 & 0.678 & 0.219 & 0.842 & 0.574 & 0.760 & 0.784 & 0.558 \\
\hline Observations & 453 & 453 & 453 & 453 & 453 & 453 & 453 & 453 & 453 \\
\hline R-squared & 0.066 & 0.082 & 0.087 & 0.061 & 0.055 & 0.057 & 0.070 & 0.046 & 0.066 \\
\hline Control group mean & 2384 & 343.1 & 87.07 & 63.57 & 83.26 & 494.8 & 786.5 & 439.8 & 86.29 \\
\hline
\end{tabular}

Notes: Robust standard errors clusterd at the level of the day and location of the baseline survey in brackets. There are 106 dayXlocation clusters in each regression. Sample is all migrant-student pairs with completed 2nd round follow-up surveys. All regressions include stratification cell fixed effects for the week and location of the baseline survey. All money amounts are in US dollars.

*** $\mathrm{p}<0.01,{ }^{* *} \mathrm{p}<0.05$, * $\mathrm{p}<0.1$ 


\section{Appendix Table 16: Target student education outcomes in 2nd follow-up}

(2013)

\begin{tabular}{|c|c|c|c|c|}
\hline & (1) & (2) & (3) & (4) \\
\hline & $\begin{array}{l}\text { Target student } \\
\text { is in school }\end{array}$ & $\begin{array}{l}\text { Target student } \\
\text { is in any } \\
\text { private school }\end{array}$ & $\begin{array}{l}\text { Target student } \\
\text { is in parochial } \\
\text { school }\end{array}$ & $\begin{array}{l}\text { Target student } \\
\text { is in other } \\
\text { private school }\end{array}$ \\
\hline \multirow[t]{2}{*}{ 3:1 match } & -0.0102 & 0.0195 & 0.0618 & -0.0424 \\
\hline & {$[0.0653]$} & {$[0.0546]$} & {$[0.0402]$} & {$[0.0440]$} \\
\hline \multirow[t]{2}{*}{ 1:1 match } & -0.0163 & 0.0833 & 0.0128 & 0.0705 \\
\hline & [0.0648] & {$[0.0541]$} & [0.0339] & {$[0.0494]$} \\
\hline \multirow[t]{2}{*}{ No match } & -0.0272 & 0.0604 & 0.0637 & -0.00335 \\
\hline & [0.0637] & {$[0.0546]$} & {$[0.0426]$} & {$[0.0524]$} \\
\hline \multicolumn{5}{|c|}{$P$-values for tests of equality of coefficients } \\
\hline $3: 1=1: 1$ & 0.932 & 0.322 & 0.274 & 0.044 \\
\hline 3:1 = No match & 0.790 & 0.562 & 0.973 & 0.475 \\
\hline 1:1 = No match & 0.873 & 0.720 & 0.223 & 0.214 \\
\hline $3: 1=1: 1=$ No match & 0.963 & 0.611 & 0.312 & 0.129 \\
\hline Observations & 459 & 459 & 459 & 459 \\
\hline R-squared & 0.070 & 0.091 & 0.054 & 0.086 \\
\hline Control group mean & 0.67 & 0.27 & 0.07 & 0.19 \\
\hline
\end{tabular}

Notes: Robust standard errors clusterd at the level of the day and location of the baseline survey in brackets. There are 106 dayXlocation clusters in each regression. Sample is all migrantstudent pairs with completed 2nd round follow-up surveys. All regressions include stratification cell fixed effects for the week and location of the baseline survey.

*** $\mathrm{p}<0.01, * * \mathrm{p}<0.05,{ }^{*} \mathrm{p}<0.1$ 
Appendix Table 17: Target student labor force outcomes in 2nd follow-up (2013)

\begin{tabular}{|c|c|c|c|c|c|c|}
\hline & $(1)$ & $(2)$ & (3) & $(4)$ & $(5)$ & $(6)$ \\
\hline & \multicolumn{6}{|c|}{ Dependent variables refer to work currently being done by the target student (2013) } \\
\hline \multirow[t]{2}{*}{$3: 1$ match } & -0.00833 & -1.210 & -0.0529 & -2.059 & 0.0628 & 0.849 \\
\hline & [0.0685] & [2.247] & [0.0586] & [2.137] & [0.0419] & [0.682] \\
\hline \multirow[t]{2}{*}{$1: 1$ match } & -0.0213 & -1.140 & -0.0641 & -2.111 & 0.0405 & 0.971 \\
\hline & [0.0652] & [2.147] & [0.0575] & [1.945] & [0.0428] & [0.789] \\
\hline No match & -0.0265 & 0.962 & -0.0316 & -0.148 & 0.00115 & 1.110 \\
\hline \multicolumn{7}{|c|}{$P$-values for tests of equality of coefficients } \\
\hline $3: 1=1: 1$ & 0.868 & 0.977 & 0.859 & 0.981 & 0.705 & 0.889 \\
\hline $3: 1=$ No match & 0.772 & 0.370 & 0.701 & 0.416 & 0.233 & 0.775 \\
\hline $1: 1=$ No match & 0.946 & 0.413 & 0.573 & 0.363 & 0.437 & 0.889 \\
\hline $3: 1=1: 1=$ No match & 0.958 & 0.618 & 0.838 & 0.609 & 0.452 & 0.959 \\
\hline Observations & 459 & 459 & 459 & 459 & 459 & 459 \\
\hline R-squared & 0.047 & 0.059 & 0.068 & 0.076 & 0.080 & 0.075 \\
\hline Control group mean & 0.33 & 8.07 & 0.21 & 6.53 & 0.13 & 1.55 \\
\hline
\end{tabular}

Notes: Robust standard errors clusterd at the level of the day and location of the baseline survey in brackets. There are 106

dayXlocation clusters in each regression. Sample is all migrant-student pairs with completed 2nd round follow-up surveys. All regressions include stratification cell fixed effects for the week and location of the baseline survey.

$* * * \mathrm{p}<0.01, * * \mathrm{p}<0.05, * \mathrm{p}<0.1$ 